\title{
Review \\ Progress in osteoporosis and fracture prevention: focus on postmenopausal women
}

\author{
Kenneth G Saag ${ }^{1}$ and Piet Geusens ${ }^{2}$
}

\begin{abstract}
1Division of Clinical Immunology and Rheumatology, Center for Education and Research on Therapeutics, University of Alabama at Birmingham, 820 Faculty Office Tower, 510 20th Street South, Birmingham, AL 35294-3708, USA

${ }^{2}$ Department of Internal Medicine, Subdivision of Rheumatology, Maastricht University Medical Center, P. Debyelaan 25, Postbus 5800,

6202 AZ Maastricht, The Netherlands \& Biomedical Research Institute, University Hasselt, Agoralaan, gebouw D, B-3590 Diepenbeek, Belgium
\end{abstract}

Corresponding author: Kenneth G Saag, ksaag@uab.edu

Published: 14 October 2009

This article is online at http://arthritis-research.com/content/11/5/251

(C) 2009 BioMed Central Ltd

Arthritis Research \& Therapy 2009, 11:251 (doi:10.1186/ar2815)

\begin{abstract}
In the past decade, we have witnessed a revolution in osteoporosis diagnosis and therapeutics. This includes enhanced understanding of basic bone biology, recognizing the severe consequences of fractures in terms of morbidity and short-term refracture and mortality risk and case finding based on clinical risks, bone mineral density, new imaging approaches, and contributors to secondary osteoporosis. Medical interventions that reduce fracture risk include sufficient calcium and vitamin $D$ together with a wide spectrum of drug therapies (with antiresorptive, anabolic, or mixed effects). Emerging therapeutic options that target molecules of bone metabolism indicate that the next decade should offer even greater promise for further improving our diagnostic and treatment approaches.
\end{abstract}

\section{Introduction}

In the past decade, we have witnessed a revolution in understanding bone biology. Major progress has also been achieved in fracture risk estimation and prevention of fractures. How does this progress translate into daily clinical practice? First, case finding of subjects at highest risk for fractures is now possible at the individual patient level, using clinical bone- and fall-related risk factors, with and without bone mineral density (BMD). Second, prevention of vertebral and nonvertebral fractures, including hip fractures, is now possible by optimizing calcium homeostasis and by appropriate medication in wellselected patients with a high risk of fracture. Recent studies indicate new possibilities for case finding, such as in vivo structural analysis of bone microarchitecture, and new molecular targets to rebalance bone remodeling. Here, we review recent progress in case-finding strategies and in the evidence that the risk of first and subsequent fractures can be prevented in daily clinical practice.

\section{The Fracture Risk Assessment Tool for calculating the individual 10-year fracture risk} The clinical expression of osteoporosis is a fragility fracture, but bone loss in and of itself is asymptomatic, which has led to the description of osteoporosis as a 'silent thief'. The asymptomatic nature of bone loss suggests that osteoporosis cannot be detected before a fragility fracture occurs, unless BMD is measured. Indeed, BMD is related to bone strength and low BMD is a major risk factor for fractures. However, most patients presenting with a fracture do not have BMDbased osteoporosis, defined according to the World Health Organization (WHO) definition as a $\mathrm{T}$ score of -2.5 or below [1]. Many qualities of bone, other than low BMD, are involved in fracture risk such as structural and material components of bone and the cellular activities and molecular signals that regulate lifelong bone remodeling under control of mechanical load, hormones, growth factors, and cytokines. Some of these characteristics of bone are measurable in clinical practice (for example, BMD, bone size, vertebral deformities and fractures, and markers of bone turnover), but many are not (for example, material properties) or are just evolving (for example, microarchitecture by microcomputer tomography or magnetic resonance imaging). In addition, and independent of bone-related risks, extraskeletal risk factors such as fall risk contribute to fracture risk and are present in the majority of patients older than 50 years presenting with a clinical fracture [1].

$\mathrm{AR}=$ absolute risk; $\mathrm{BMD}=$ bone mineral density; $\mathrm{Cl}=$ confidence interval; $\mathrm{DXA}=$ dual-energy $\mathrm{x}$-ray absorptiometry; ERT $=$ estrogen replacement therapy; FIT = Fracture Intervention Trial; FRAX = Fracture Risk Assessment Tool; GI = gastrointestinal; ISCD = International Society of Clinical Densitometry; MORE = Multiple Outcomes of Raloxifene Evaluation; NOF = National Osteoporosis Foundation; NOGG = National Osteoporosis Guideline Group; NOS = National Osteoporosis Society; OPG = osteoprotegerin; PTH = parathyroid hormone; RANK = receptor activator of nuclear factor-kappa B; RANKL = receptor activator of nuclear factor-kappa B ligand; RR = relative risk; RRR = relative risk reduction; SERM $=$ selective estrogen receptor modulator; VFA = vertebral fracture assessment; WHI = Women's Health Initiative; WHO = World Health Organization. 
Large-scale prospective population studies have enabled the specification of clinical risk factors for fractures that are independent of low BMD and have allowed quantification of their relative risks (RRs) for predicting fractures. Thus, many aspects of osteoporosis and fracture risk are clinically recognizable (such as age, gender, and body weight), even before a first fracture has occurred. However, RRs are difficult to apply in daily clinical practice since their clinical significance depends on the prevalence of fractures in the general population. From this observation and for the purpose of clinical application, the concept of the absolute risk (AR) of fractures has emerged and refers to the individual's risk for fractures over a certain time period (for example, over the next 10 years) [2].

During the last decade, the development of the Fracture Risk Assessment Tool (FRAX) algorithm as a clinical tool for calculation of fracture risk in the individual patient is a major achievement in the field of case finding $[2,3]$. The FRAX is based on large-scale prospective population-based studies and includes age, gender, body weight and body mass index, a history of fracture, hip fracture in parents, current smoking, excessive alcohol intake, rheumatoid arthritis, glucocorticoid use, and other forms of secondary osteoporosis (Table 1). The WHO developed FRAX especially for primary care physicians for calculating the individual 10-year risk of hip and major fractures (defined as clinical spine, forearm, hip, or humerus fracture) in daily practice in women and men, based on the above-mentioned clinical risk factors, with and without results of BMD measurement in the femoral neck.

\section{Strengths of the Fracture Risk Assessment Tool}

FRAX is based on a large sample of primary data of prospective population studies and takes into account variability in fracture probability between geographic regions. FRAX should not be considered a gold standard but rather a platform technology and provides an aid to enhance patient assessment. FRAX can be integrated in clinical practice in many countries worldwide, both in women and men. FRAX is therefore likely to become, in many countries, the most popular instrument for identifying women and men at highest risk for fractures.

FRAX has been included in guidelines as a tool for case finding for identifying postmenopausal women at high risk for fractures, for selecting subjects to measure BMD, and for treatment decisions. The National Osteoporosis Foundation (NOF) in the US and the National Osteoporosis Society (NOS) in the UK have recently updated their guidelines on postmenopausal osteoporosis in this context (Figure 1) [4,5]. These groups have integrated FRAX and BMD for case finding of individuals at high risk for fracture and for treatment decisions. Both sets of guidelines make a clear distinction between postmenopausal women with and without a fracture history. This is a major step forward in the clinical applicability for postfracture treatment in patients presenting with a
Table 1

Clinical risk factors and bone densitometry results that are included in the Fracture Risk Assessment Tool algorithm

Age

Gender

Body mass index

History of fracture after the age of 45 to 50 years

Parent with hip fracture

Current smoking

Alcohol intake of greater than 2 units per day

Glucocorticoid use

Rheumatoid arthritis

Other causes of secondary osteoporosis:

- Untreated hypogonadism in men and women, anorexia nervosa, chemotherapy for breast and prostate cancer, and hypopituitarism

- Inflammatory bowel disease and prolonged immobility (for example, spinal cord injury, Parkinson disease, stroke, muscular dystrophy, and ankylosing spondylitis)

- Organ transplantation

- Type I diabetes and thyroid disorders (for example, untreated hyperthyroidism and overtreated hypothyroidism)

Results of bone densitometry using dual-energy $x$-ray absorptiometry of the femoral neck.

fracture. Based on the fracture risk profile, the NOS, together with the National Osteoporosis Guideline Group (NOGG) and the Royal College of Physicians, determined treatment thresholds at which fracture prevention became cost-effective (Figure 2) [2,5].

\section{Postmenopausal women with a history of fractures}

The NOS advocates drug treatment in all postmenopausal women with a history of any fragility fracture (defined as distal radius, proximal humerus, spine [including morphometric vertebral fracture], pelvis [pubic rami], tibia, and ankle) [5]. The NOF advocates drug treatment in postmenopausal women with a vertebral or hip fracture (without need of BMD or FRAX for decisions about pharmacotherapy), but after a nonvertebral nonhip fracture, the NOF advocates performing a dual-energy x-ray absorptiometry (DXA) measurement and starting drug treatment in patients having osteoporosis and in patients with osteopenia when FRAX indicates a 10-year fracture probability of at least 3\% for hip or at least 20\% for major fractures. Thus, in postmenopausal women with a history of vertebral or hip fracture, neither set of guidelines uses FRAX for decisions about drug treatment (and neither does the NOS for after any fragility fracture), and both sets consider such fracture history by itself as a starting point for case finding and treatment decisions. 


\section{History of fracture}

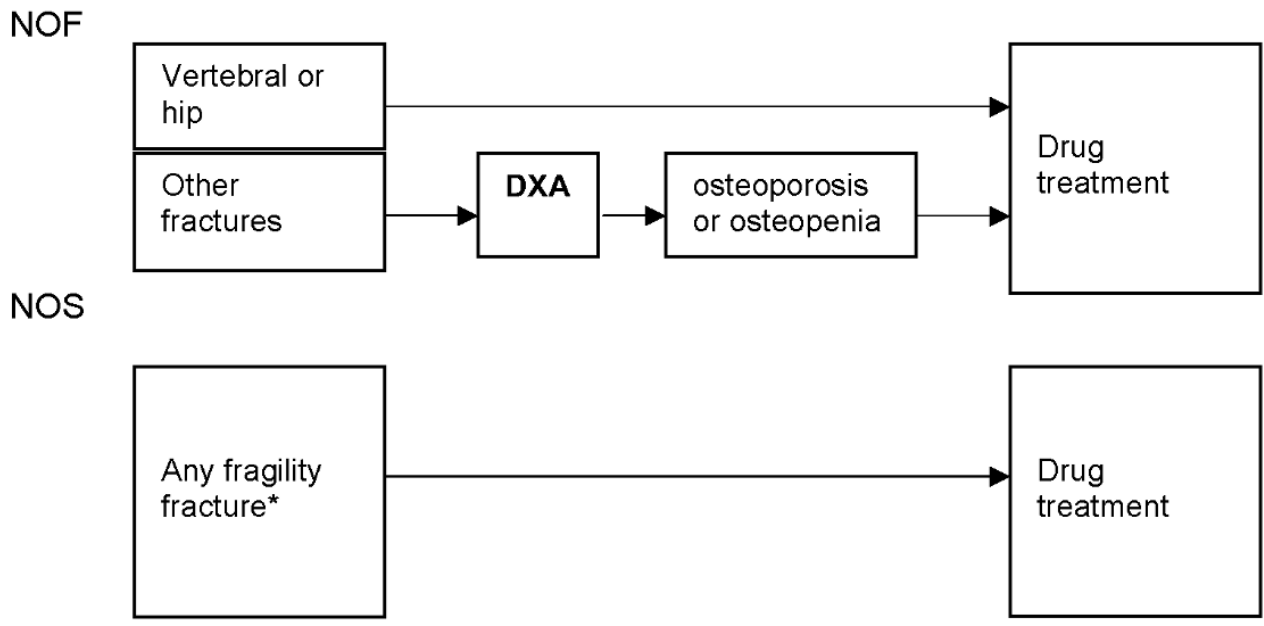

\section{No history of fracture}

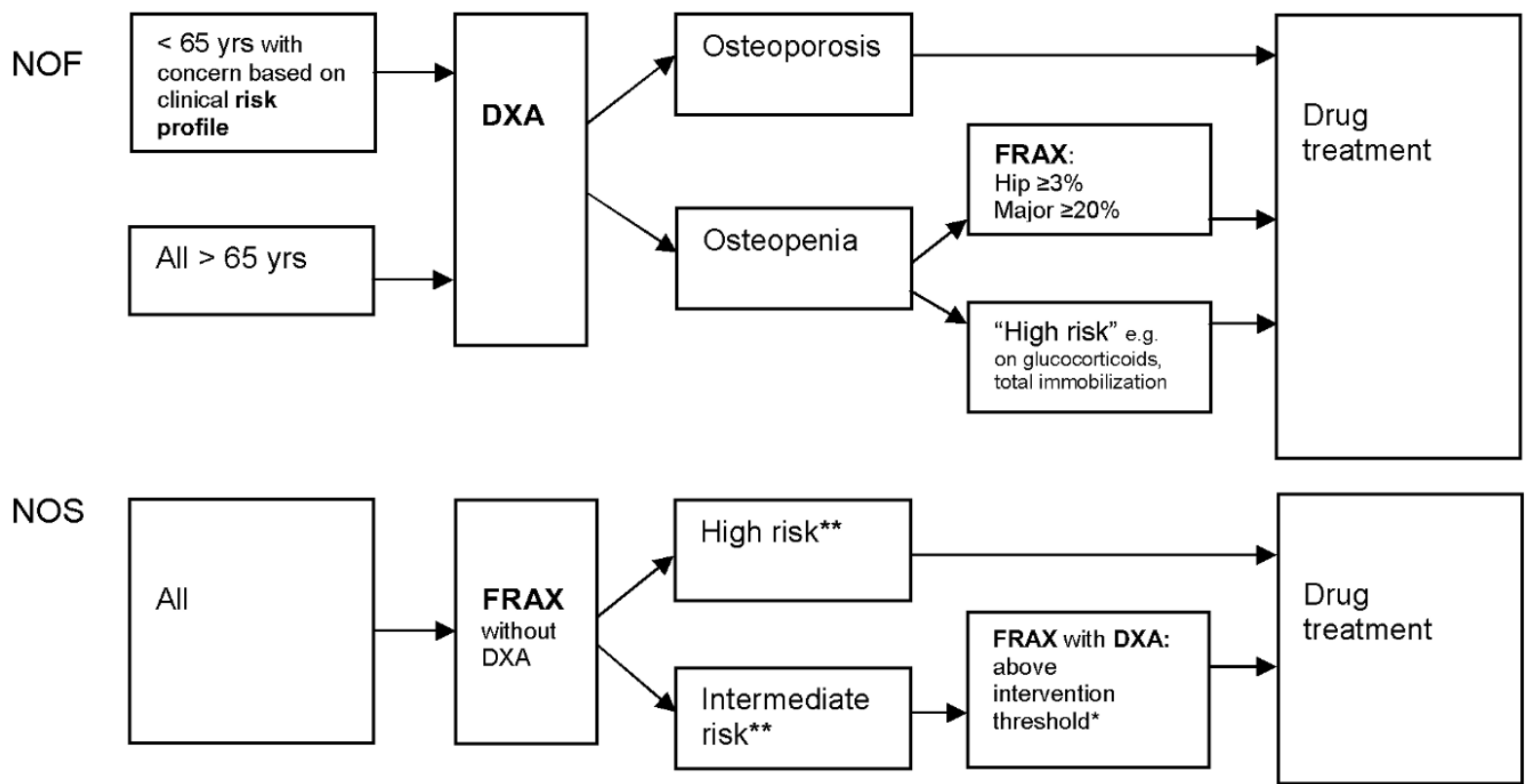

Algorithms for case finding and drug treatment decisions in postmenopausal women with and without a history of fractures according to the National Osteoporosis Foundation (NOF) in the US and the National Osteoporosis Society (NOS) in the UK. DXA, dual-energy x-ray absorptiometry; FRAX, Fracture Risk Assessment Tool. *Previous fragility fracture, particularly of the hip, wrist and spine including morphometric vertebral fracture. ${ }^{*}$ Based on UK guidelines by NOGG.

\section{Postmenopausal women without a fracture history}

The NOS advocates applying FRAX (without BMD) in all postmenopausal women. Women at high risk according to FRAX without BMD are then considered candidates for drug treatment. Women with an intermediate risk according to FRAX without BMD are recommended to have a DXA measurement, and when FRAX with BMD is above the intervention threshold according to the NOGG, drug treatment should be considered.

The NOF advocates using DXA in all women older than 65 years and in postmenopausal women younger than 65 years in whom there is concern about their fracture risk 


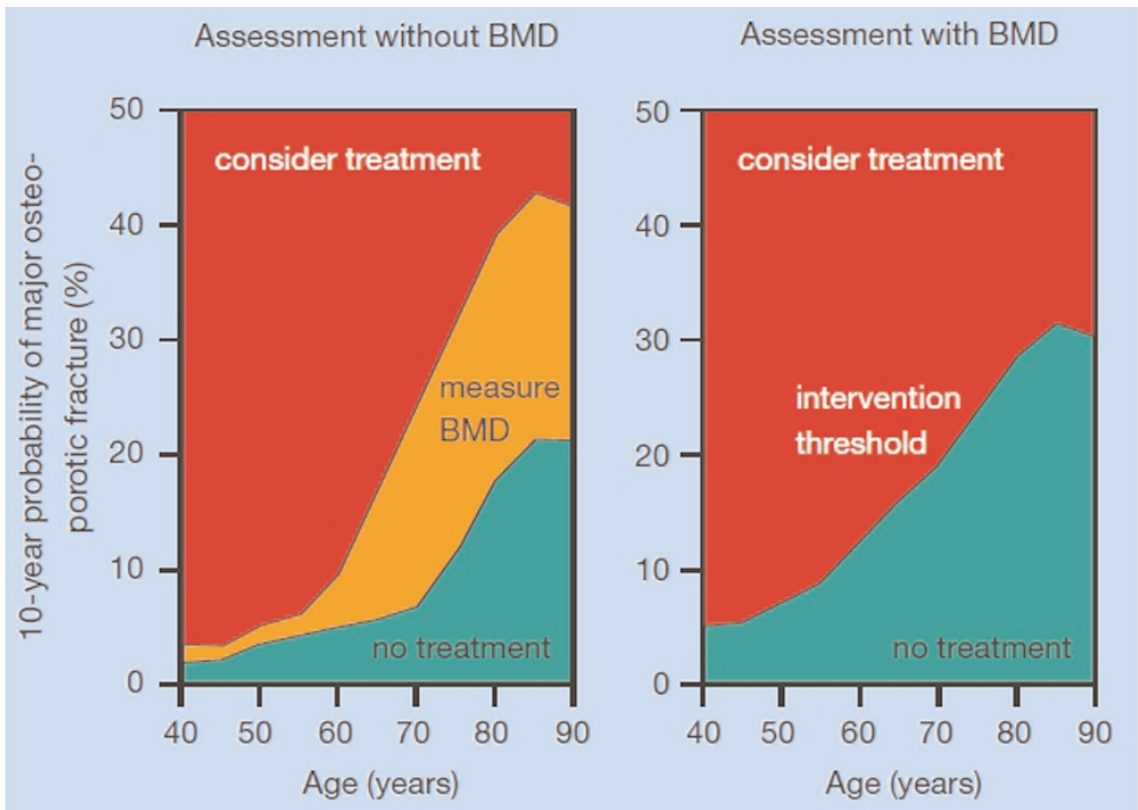

Assessment and intervention thresholds based on the 10-year risk of major fracture, as proposed in the UK [2]. BMD, bone mineral density. With kind permission from Springer Science+Business Media [5].

based on the presence of clinical risk factors. This approach suggests that all postmenopausal women under 65 years of age should be clinically classified as having at least one of the risk factors of FRAX. Treatment is then recommended in patients with osteoporosis, in patients with osteopenia when the FRAX indicates a 10-year risk of greater than 3\% for hip fractures or greater than $20 \%$ for major osteoporotic fractures, and in other patients considered at high risk (on glucocorticoids, total immobilization). These upgraded guidelines indicate that FRAX is an emerging tool in clinical decision making about case finding, selecting patients for DXA, and treatment decisions in postmenopausal women without a fracture history. Patients with a fracture are considered at high enough risk to make treatment decisions without additional need for using FRAX. It is expected that FRAX will also be helpful in designing fracture prevention studies and in reimbursement issues. In a study from Switzerland, profiles of patients at increased probability of fracture beyond currently accepted reimbursement thresholds for bone BMD measurement by DXA and osteoporosis treatment were identified and constitute an additional group of patients in whom treatment should be considered [6].

\section{Limitations of the Fracture Risk Assessment Tool}

In spite of its solid scientific basis and clinical attractiveness, FRAX has several limitations, as acknowledged by the authors (Table 2) [2]. Meanwhile, FRAX has been integrated in guidelines/guidance in the US, UK, Europe, Canada, Germany, and Japan [2], but with different approaches for diagnostic and treatment thresholds, as shown above for the NOS and the NOF $[4,5]$. Fracture reduction has been demonstrated in randomized controlled clinical trials in patients selected on the basis of the presence of a morphometric vertebral fracture, hip fracture, or a low BMD, but not on the basis of FRAX. Therefore, of great interest is the finding that fracture reduction was greater at higher fracture probabilities based on FRAX, with or without BMD. Antifracture efficacy was evident when baseline fracture probabilities for major fractures were greater than $20 \%$ in the clodronate trial (in preventing major fractures) [7] and greater than $16 \%$ in the bazedoxifene trial (in preventing clinical fractures), irrespective of whether BMD was used in the fracture calculation [2]. Further studies will be needed on the ability of treatment to reduce fracture risk in subjects at high risk for fractures based on FRAX in the absence of a morphometric vertebral fracture, hip fracture, or a low BMD, which is the case in most patients presenting with a nonvertebral fracture. Decisions on treatment thresholds will furthermore depend on factors related to health care providers and patients and the willingness of society to reimburse treatment as health economic aspects are becoming increasingly important to determine the costeffectiveness of treatment. Meanwhile, the NOGG of the UK has indicated FRAX-based thresholds for measuring BMD and for treatment decisions, with and without BMD (Figure 2). The management algorithms proposed by the NOGG are underpinned by a health economic analysis applied to the epidemiology of fracture in the UK. 
Table 2

\section{Limitations of the Fracture Risk Assessment Tool for case finding}

- Factors not included in FRAX:

- The 'dose effect' of some risk factors

- Glucocorticoid use (dose and duration)

- Characteristics of previous fractures (location, number, and severity)

- Fall risks

- Vitamin D deficiency

- Fluctuation over time of subsequent fracture

- Markers of bone formation and bone resorption

- How to identify patients with a vertebral fracture

- Which laboratory tests are indicated (and in whom) to exclude secondary osteoporosis

- FRAX is applicable only in untreated patients.

- Inclusion of BMD results is limited to results of BMD in the femoral neck. However, total hip BMD can be used interchangeably with femoral neck BMD in women, but not in men.

- FRAX does not indicate which intervention is indicated at which level of 10-year fracture risk of hip or major fractures (for either nonpharmacological or drug treatment).

BMD, bone mineral density; FRAX, Fracture Risk Assessment Tool.

Fall-related risks were explicitly excluded from the FRAX calculations but were recognized as risks for fractures independently of bone-related risks, especially for nonvertebral fractures such as hip fractures. More than $80 \%$ of women and men presenting with a clinical fracture to the emergency unit have, beside bone-related risks, one or more fall-related risks and have, independently from BMD, a fourfold increased risk of a fall history during the previous year [1]. In an integrated bone- and fall-related risk evaluation tool for the estimation of the 5- and 10-year ARs for fractures in patients using glucocorticoids, a history of falls had a greater impact on fracture risk than any other evaluated risk, and its contribution to fracture risk was similar to, and independent of, using a high dose of glucocorticoids (prednisone greater than $15 \mathrm{mg} /$ day) [8]. Thus, with FRAX, fracture risk calculation could be underestimated in patients with fall risks.

\section{Subsequent fractures and postfracture mortality cluster in time: the need for immediate clinical attention in patients presenting with a fracture}

A history of nonvertebral fracture is associated with a doubling of the risk of a subsequent fracture, and the subsequent fracture risk is even quadrupled after a vertebral fracture. However, this re-fracture risk is not constant over time and is driven by the high, threefold to fivefold increase in the years immediately after a first fracture, followed by a gradual waning later on (Figure 3) [9]. This has been shown for repeat morphometric vertebral fractures, subsequent clinical spine, forearm, and hip fractures after hospitalization because of a vertebral fracture, repeat low trauma fractures in subjects older than 60 years, repeat clinical vertebral and nonvertebral fractures from menopause onwards, and repeat hip fractures [9-12]. As a result, it has been shown in longterm follow-up studies that $40 \%$ to $50 \%$ of all subsequent fractures occur within 3 to 5 years after a first fracture. The clinical implication is that patients older than 50 years presenting with a fracture need immediate attention to reduce the risk of a subsequent fracture. This is a situation in which it is important to take immediate action in fracture patients, such as a fracture liaison service and other initiatives in the field of postfracture care $[13,14]$. It also indicates that, in such patients, treatment that has been shown to reduce fracture risk within the short term should be started [15].

An increased risk of mortality has been found after hip, vertebral, and several nonhip, nonvertebral fractures [16]. As for subsequent fracture risk, this increase in mortality is higher immediately after fracture than later on. In women and men older than 60 years, nearly $90 \%$ of excess deaths related to fracture over the 18 years of observation occurred in the first 5 years. Of the 5-year excess mortality, hip, vertebral, and nonhip, nonvertebral fractures were each associated with approximately one third of deaths. The major causes of death were related to cardiovascular and respiratory comorbidity [16].

\section{Assessment of vertebral fractures: an opportunity to identify high-risk patients}

Vertebral fractures are a special group of fractures. Morphometric vertebral fractures are the most frequent fractures in women and men older than 50 years [17] and their presence is a strong predictor of future vertebral, nonvertebral, and hip fracture risk [18]. Clinical vertebral 
Figure 3
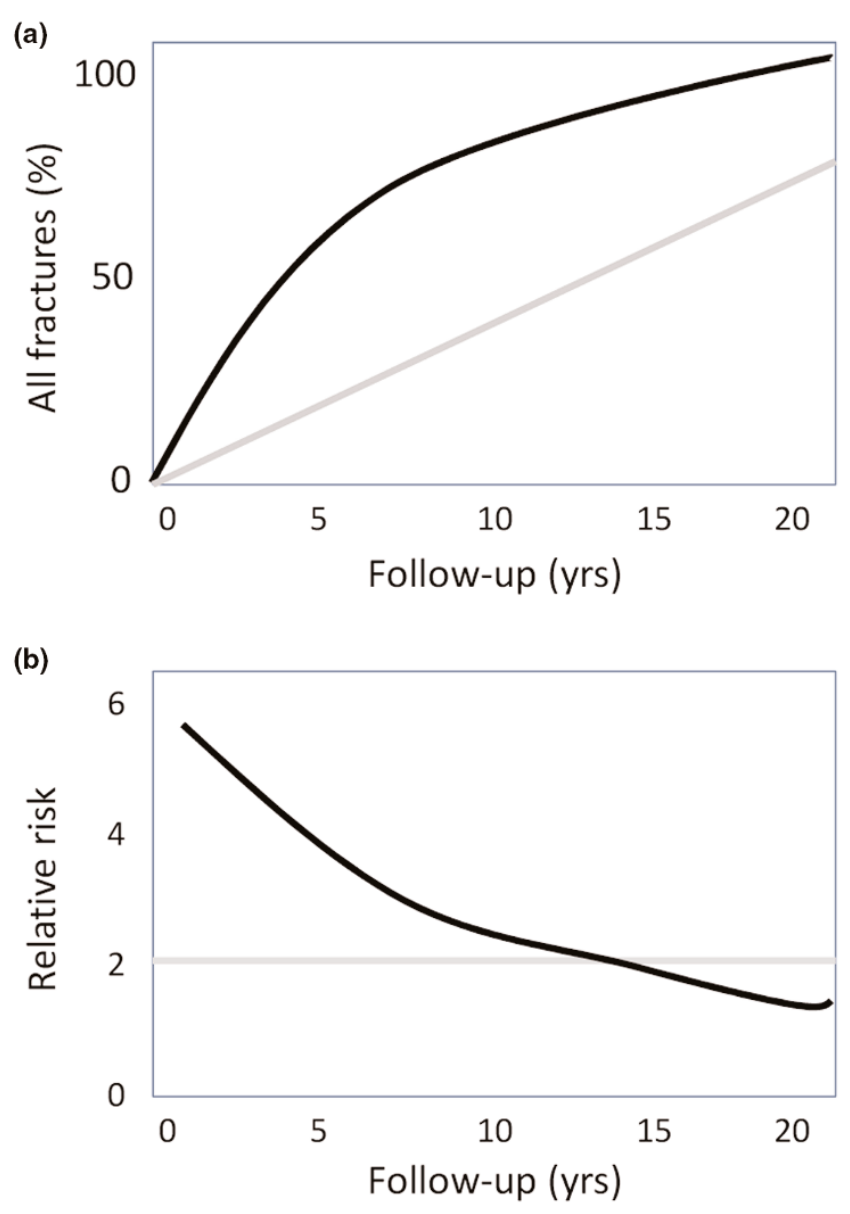

Risk of first and subsequent fracture over time. (a) Percentage of all first fractures from menopause onwards (grey line) and fractures subsequent to initial fractures (black line). (b) Relative risk of all subsequent fractures calculated as a mean from the time of first fracture (grey line) and per separate year of follow-up after a first fracture (black line).

fractures represent one out of three to four morphometric vertebral fractures and represent less than $10 \%$ of all fractures in patients presenting with a fracture to the emergency department [1]. Most morphometric vertebral fractures are not diagnosed until clinically suspected (for example, significant height loss, hyperkyphosis, protruding abdomen, rib-iliac crest distance of less than $2 \mathrm{~cm}$, and acute or chronic back pain) and imaging by $x$-ray is performed. But even when lateral $x$-rays of the spine are available, vertebral fractures are often missed $[18,19]$.

Vertebral fracture assessment (VFA) is a new method to evaluate the presence of morphometric vertebral fractures and deformities using x-ray absorptiometry (Figure 4) [19]. With appropriate DXA devices, VFA can be performed at the occasion of a bone densitometry. Advantages are its low irradiation, the availability of semiautomatic image analysis tools to assist in measuring vertebral shapes of the individual vertebrae, its plan-parallel projection, and its high negative predictive value. Disadvantages include difficulties in measuring upper thoracic vertebrae due to overlying soft tissue and ribs.

The prevalence of previously unknown morphometric vertebral fractures has been studied in various at-risk populations. In a recent study of women and men presenting with a nonvertebral fracture, one out of four had a prevalent morphometric vertebral fracture on VFA that was not recognized previously [14]. In one other study, the prevalence of morphometric vertebral fractures was $21 \%$ in postmenopausal women with osteopenia [20]. The authors concluded that the use of VFA contributed to better define the fracture risk in patients presenting with a nonvertebral fracture and in women with osteopenia and contributed to treatment decisions by identifying patients at high risk of fractures in the absence of BMD osteoporosis. VFA also helps to select patients in whom x-rays of the spine are indicated to differentiate changes in shape from normal variations and diseases such as Scheuermann disease, pathologic fractures, bone remodeling in the context of osteoarthritis, and developmental short vertebral height [19]. According to the International Society of Clinical Densitometry (ISCD), additional $\mathrm{x}$-ray imaging is needed in cases of two or more mild (grade 1) deformities without any moderate or severe (grade 2 or 3 ) deformities, when lesions in vertebrae cannot be ascribed to benign causes, or when vertebral deformities are found in a patient with a known history of a relevant malignancy [19]. In patients with BMD-diagnosed osteoporosis, a baseline VFA is not necessary for treatment decisions but can be helpful to identify during follow-up whether a vertebral fracture is new or old [15]. Indications for VFA according to the ISCD are shown in Table 3 [19].

\section{Differential diagnosis in patients with osteoporosis or a fragility fracture or both}

Randomized controlled trials on fracture prevention in postmenopausal women exclude patients with secondary osteoporosis, except in studies in glucocorticoid users. However, patients with BMD-diagnosed osteoporosis or presenting with a clinical fracture or both often have contributors to secondary osteoporosis. FRAX includes a long list of causes of secondary osteoporosis that contribute to fracture risk independently of other clinical risks and BMD (Table 1) $[2,3]$. Differential diagnosis in the context of case finding therefore includes a thorough medical history and clinical examination. Based on FRAX, laboratory investigations can contribute to case finding, but FRAX does not give instructions on how to exclude other contributors to secondary osteoporosis that are frequently found in patients with osteoporosis or fractures or both [21,22]. In patients with BMD-based osteoporosis or presenting with a clinical fracture or both, diagnostic evaluation is necessary and should include serum 25-(OH)D3, calcium, creatinine, thyroid-stimulating hormone, parathyroid 


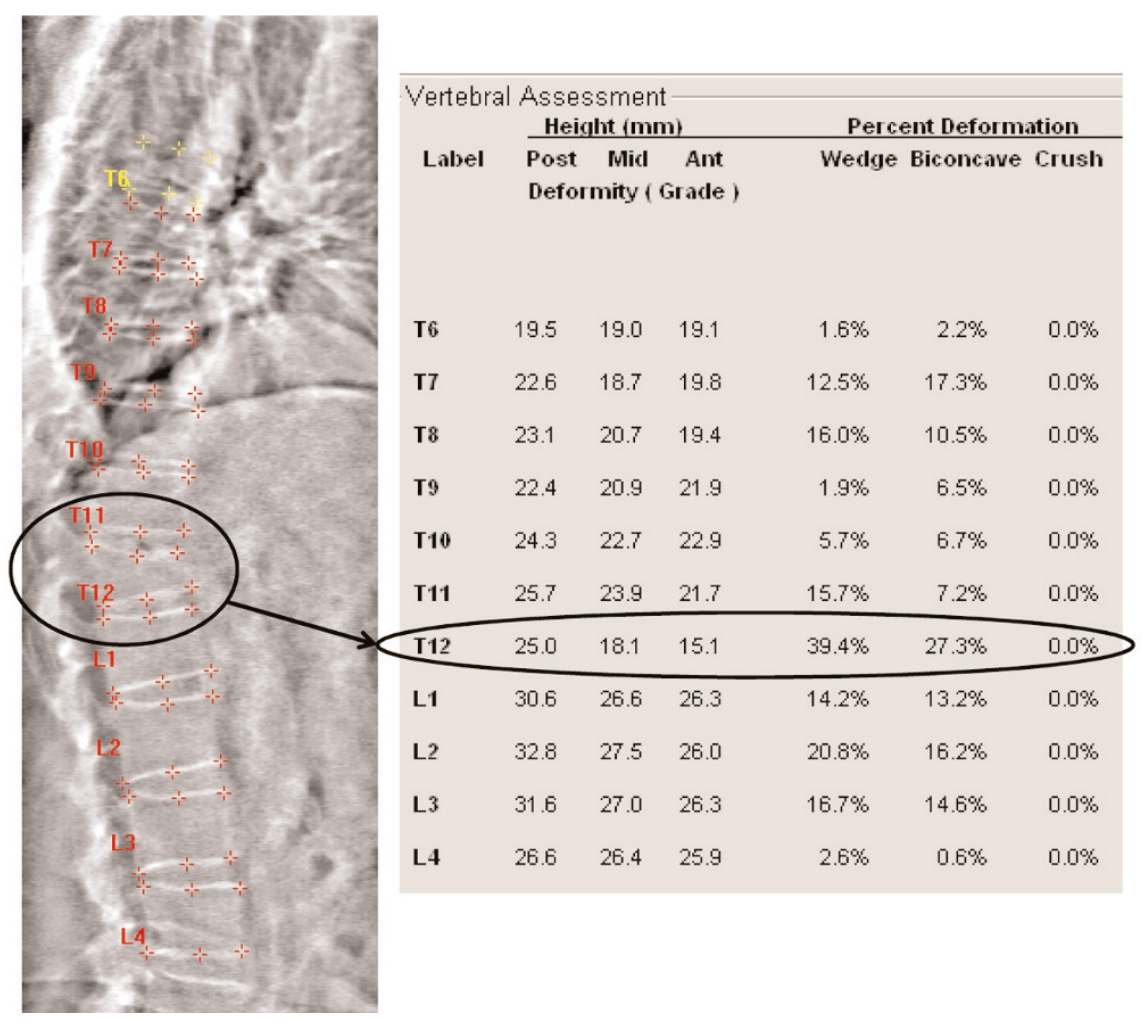

Example of using dual-energy $x$-ray absorptiometry technology for vertebral fracture assessment.

hormone (PTH), testosterone (in men) and, of 24-hour urine, calcium and creatinine [21-23]. According to the clinical picture and suspicion, other serum measurements such as plasma cortisol, hemoglobin, white blood cell count, serum/urine protein electrophoresis, and selected other evaluations looking for secondary causes are indicated.

Only limited studies about the prevalence of secondary osteoporosis in daily practice have been published during the last decade. In patients referred for DXA in the clinical context of an osteoporosis clinic, contributors to secondary osteoporosis were already documented in one out of three postmenopausal women with osteoporosis [21]. In the group of otherwise presumably healthy women, previously undiagnosed contributors were found in an additional $30 \%$ of women [21]. In women and men presenting with a clinical fracture at the emergency unit and having BMD osteoporosis, $42 \%$ had contributors to secondary osteoporosis, mainly vitamin D deficiency [22].

Vitamin D deficiency is endemic worldwide [24] but is not included in the FRAX algorithm. Vitamin D deficiency was found to be the main contributor to secondary osteoporosis in postmenopausal women with BMD osteoporosis [21], in women and men presenting with a clinical fracture and having
BMD osteoporosis [22], and in patients presenting with a hip fracture [25]. Recent data indicate that vitamin D is an independent risk for fractures [26], and meta-analyses indicate that correction of vitamin $D$ deficiency results in a decreased fall and fracture risk [27,28], but the effects depend on the dose of vitamin $D$ and the target population [29]. Frail older people confined to institutions may sustain fewer hip fractures if given vitamin D with calcium. Vitamin D alone is unlikely to prevent fracture [30].

It is still a matter of debate which dose of vitamin $D_{3}$ (or potentially $D_{2}$ ) supplementation is necessary/optimal, taking into account baseline vitamin $D$ status and the desired serum levels to be achieved by supplementation [31-33]. Clearly, an intake of $400 \mathrm{lU} /$ day is not sufficient [31-34]. A daily intake of 800 to $1,600 \mathrm{IU}$ in healthy adults will increase serum levels above $75 \mathrm{nmol} / \mathrm{L}$ in half of the population [33]. Others suggest that 1,000 to $1,200 \mathrm{lU} /$ day is necessary in addition to typical food and cutaneous inputs to achieve a target serum level of $80 \mathrm{nmol} / \mathrm{L}$ (32 ng/mL) [31].

Lifelong milk intake is not related to fracture risk [35], but in several reviews, the necessity of addition of calcium to vitamin $D$ for fracture prevention was stressed and a dose of 1,000 to $1,200 \mathrm{mg} /$ day was advocated [34,36]. However, in 
Table 3

\section{Indications for vertebral fracture assessment using x-ray absorptiometry [19]}

1. Postmenopausal women with low bone mass (osteopenia) by BMD criteria plus one of the following:

- Age of greater than or equal to 70 years.

- Historical height loss of greater than $4 \mathrm{~cm}$.

- Prospective height loss of greater than $2 \mathrm{~cm}$.

- Self-reported prior vertebral fracture (not previously documented).

- Two or more of the following:

Age of 60 to 69 years.

Self-reported prior nonvertebral fracture.

Historical height loss of 2 to $4 \mathrm{~cm}$.

Chronic systemic diseases associated with increased risk of vertebral fractures (for example, moderate to severe COPD, seropositive rheumatoid arthritis, and Crohn disease).

2. Men with low bone mass (osteopenia) by BMD criteria plus one of the following:

- Age of 80 years or older.

- Historical height loss of greater than $6 \mathrm{~cm}$.

- Prospective height loss of greater than $3 \mathrm{~cm}$.

- Self-reported vertebral fracture (not previously documented).

- Two or more of the following:

Age of 70 to 79 years.

Self-reported prior nonvertebral fracture.

Historical height loss of 3 to $6 \mathrm{~cm}$.

On pharmacological androgen deprivation therapy or following orchiectomy.

Chronic systemic diseases associated with increased risk of vertebral fractures (for example, moderate to severe COPD, seropositive rheumatoid arthritis, and Crohn disease).

3. Women or men on chronic glucocorticoid therapy (equivalent to $5 \mathrm{mg}$ or more of prednisone daily for 3 months or longer).

4. Postmenopausal women or men with osteoporosis by bone density criteria (total hip, femoral neck, or lumbar spine T score of not more than $-2.5)$ if documentation of one or more vertebral fractures will alter clinical management.

$\mathrm{BMD}$, bone mineral density; COPD, chronic obstructive pulmonary disease.

studies published in 2008, supplements of $1,000 \mathrm{mg}$ calcium/day in healthy postmenopausal women [37] and healthy men [38] with a mean baseline calcium intake of $800 \mathrm{mg} /$ day were associated with an increased risk of vascular events, including myocardial infarction. These studies raised considerable controversy and suggested the need for further research [39]. In this context, it is reassuring that, when intake of vitamin $D_{3}$ is sufficient, the need for calcium intake is considered to be lower [32,40-42]. Indeed, if dietary calcium is a threshold nutrient, as suggested by Heaney [41], then the threshold for optimal calcium absorption may be at a lower calcium intake when vitamin $D$ nutrition is higher. Until well-designed studies address the current uncertainties, the possible detrimental effect (for example, hypercalcemia and its complications) of higher-than-recommended calcium intake should be balanced against the likely benefits of calcium on bone, particularly in older women [43]. It should be noted that all clinical trials with drug therapy for osteoporosis (bisphosphonates and so on) have been conducted with the concomitant use of calcium and vitamin D supplementation.

It is generally considered that secondary causes of osteoporosis are more common in men than women, with the exception of hormone deficiency, which is characteristic after menopause, whereas andropause, depending on its definition, is found in only a subgroup of older men or men with osteoporosis [44]. Hypogonadism resulting from the treatment of breast and prostate cancer is recognized as an emerging clinical problem [45]. Cancer treatment-induced bone loss with adjuvant endocrine therapy with an aromatase inhibitor or androgen deprivation can be considered a risk factor for the development of osteopenia, osteoporosis, and bone fracture, which can be mitigated by appropriate bisphosphonate therapy [45]. Other, less common, risk factors for osteoporosis and fractures but commonly present 
in patients with low BMD or presenting with a fracture and that are not part of FRAX include the use of medications (for example, anticonvulsants, primary hyperparathyroidism, renal insufficiency, gastrectomy, Cushing syndrome, dementia, and chronic pulmonary and/or liver diseases).

\section{Fall prevention measures}

Vitamin D supplements decrease the risk of falls, as discussed above. Extraskeletal measures that are advocated in guidelines include avoidance of immobility, stimulation of weight-bearing exercise, and physiotherapy. Recent systematic reviews indicate that these measures still need more research to specify their role in the prevention of fractures. Fall prevention interventions that are likely to be effective in older people are now available [46]. Less is known about their effectiveness in preventing fall-related injuries, and no data that fall prevention decreases the risk of fracture are available. Exercise interventions reduce the risk and rate of falls in older people living in the community [47]. The role of hip protectors remains controversial in light of low acceptance and low acceptability and adherence due to discomfort and practicality $[48,49]$.

\section{Advances in osteoporosis pharmacotherapy: more than a decade of progress}

Beyond the need for sufficient calcium, vitamin D, and exercise, the past decade has seen an emergence of new data supporting a growing armamentarium of therapeutics for osteoporosis. Pharmacological therapies useful in the prevention and treatment of osteoporosis affect bone remodeling by either inhibiting bone resorption or enhancing bone formation. The majority of the agents currently licensed in both the US and other countries inhibit bone resorption. Recombinant PTH (teriparatide), on the other hand, is a bone anabolic agent. Strontium ranelate has a dual effect on bone remodeling: it stimulates bone formation and inhibits bone resorption, as shown in animal models, but is not available in the US. Despite an increasing number of well-designed studies providing evidence for pharmacotherapies in reducing primary or secondary fracture risk, many high-risk patients are not treated [50], and for patients who initiate therapy, adherence to therapy is commonly below $50 \%$ at 1 to 2 years [51].

\section{Estrogen}

Estrogen has a direct effect on bone mass through receptors on osteoclasts and other bone cells and it results in lowered bone turnover and resorption. Observational studies have suggested a $25 \%$ to $70 \%$ risk reduction for fractures associated with the use of estrogen replacement therapy (ERT) [52-55]. Results from the Women's Health Initiative (WHI), a study of over 16,000 postmenopausal women, convincingly confirmed a significant risk reduction of hip fractures attributed to combined conjugated equine estrogen and medroxyprogesterone ( $R \mathrm{R}=0.66,95 \%$ confidence interval [Cl] 0.45 to 0.98) [56] as well as estrogen alone in those women who had undergone hysterectomy [57]. In addition to its beneficial effects on bone, ERT raises highdensity lipoproteins and lowers low-density lipids in postmenopausal women $[58,59]$. Although a number of observational studies, including the Nurses Health Study [60], have reported a $35 \%$ to $80 \%$ reduction in cardiovascular events and prolonged survival among women with coronary heart disease compared with nonusers [61-65], results from the $\mathrm{WHI}$ and other studies of both primary and secondary cardiovascular prevention refute this conclusion [56,62,66,67]. Data from the WHI found a nearly 30\% increased risk of coronary heart disease and an over $40 \%$ increased risk of stroke.

Beyond heart disease, three significant concerns with estrogen are an increased risk of thromboembolic events [68], hyperplastic effects on the endometrium (potentially leading to endometrial cancer), and a heightened risk for breast cancer. The WHI [56] and other studies [69] have shown a $26 \%$ to $35 \%$ increased risk of breast cancer. Some [70], but not all [71], studies suggest that invasive breast tumors that develop among estrogen users have a more favorable histologic prognosis and that lobular cancer is more common than ductal cancer [72].

The decision to initiate ERT should be individualized and based on a balanced assessment of risk and benefits by the physician and patient [73,74]. Lower-dose estrogen can increase bone mass, may have a lower adverse effect profile, and raises interest in further study of this possible approach $[75,76]$. The proven increased risks for breast cancer and hypercoagulability and the higher risks of both primary and secondary cardiovascular disease (at least among older women) offset bone benefits and have substantially diminished enthusiasm for long-term higher-dose estrogen historically used by many patients. Although questions about the relative benefit and risks of different estrogen types, routes of administration (oral versus transdermal), administration protocols (opposed by progestins versus unopposed), and variable risk profiles based on a woman's age and comorbidities persist, current recommendations support restricting the use of estrogen in most women to the perimenopausal period $[77,78]$ and not with the primary aim to prevent fractures in the context of treatment of osteoporosis. Furthermore, the growing array of alternative bone-directed medications now available further restrict the estrogen niche.

\section{Selective estrogen receptor modulators}

Selective estrogen receptor modulators (SERMs) are nonsteroidal synthetic compounds that have estrogen-like properties on the bone and cardiovascular systems yet are estrogen antagonists to the breast and, in some cases, the endometrium. The first SERM developed both for breast cancer prevention and for osteoporosis, raloxifene, is now licensed in many countries for osteoporosis [79]. After 3 
years of follow-up in the Multiple Outcomes of Raloxifene Evaluation (MORE), a multicenter study of over 7,700 postmenopausal women with at least one vertebral fracture or osteoporosis on the basis of a $T$ score of -2.5 or below, $60 \mathrm{mg} /$ day of raloxifene reduced vertebral fracture risk by $30 \%$ [80]. This decline in fracture risk at the spine was of a magnitude similar to that seen with more potent antiresorptive agents such as the aminobisphosphonates and emphasized the importance of attenuation of bone turnover, in addition to effects on BMD, for fracture risk reduction [81,82]. Similar to tamoxifen, the risk of invasive breast cancer was decreased by $72 \%$ during the MORE study $[83,84]$, particularly among women with higher estradiol levels $[85,86]$. Hot flashes and other menopausal symptoms may recur on raloxifene. Also similar to estrogen, with raloxifene, there is an increase in lower-extremity edema as well as a roughly threefold increased risk of deep venous thrombosis [80]. Additional SERMs, such as bazedoxifene and lasofoxifene, are under development. Bazodoxifene decreases vertebral fracture risk to a degree similar to that of raloxifene (approximately 40\% over a 3-year period [87]) and, in a post hoc analysis, reduced the risk of nonspine fractures in a subgroup of patients with high risk for fractures based on the FRAX algorithm [2]. Preliminary results from the PEARL (Postmenopausal Evaluation And Risk reduction with Lasofoxifene) trial showed significant reductions compared with placebo in vertebral and nonvertebral (but not hip) fracture risk as well as in estrogen receptor breast cancer with the $0.5 \mathrm{mg}$ dose [88]. This is the only SERM, to date, that has primary data on nonvertebral fracture risk reduction. Of potential concern, a small rise in overall mortality was reported in the $0.25 \mathrm{mg}$ dose but not in the $0.5 \mathrm{mg}$ dose.

\section{Calcitonin}

Randomized controlled trials of both injectable [89-91] and intranasal [92-95] calcitonin for treatment of established postmenopausal osteoporosis have consistently shown either stabilization of BMD or small, but significant, increases in vertebral BMD of approximately $1 \%$ to $3 \%$ on $200 \mathrm{IU}$ daily for over 3 to 5 years. Beneficial BMD effects at the hip have not yet been reported. Modest increases in vertebral BMD with intranasal calcitonin are accompanied by significant declines in biochemical measures of bone resorption [96]. A 5-year multicenter study of 1,255 postmenopausal women showed a $36 \%$ reduction in vertebral fractures in the $200 \mathrm{IU}$, but not in the 100 or $400 \mathrm{IU}$, dosage group. Interpretation of study results was further limited by an approximately $50 \%$ dropout rate $[97,98]$. Nasal calcitonin is generally well tolerated, with occasional rhinitis. Headache, flushing, nausea, and diarrhea have been reported more commonly with subcutaneous rather than with intranasal calcitonin. On the basis of data that are somewhat weaker than those of osteoporosis drugs (including the absence of data on hip or nonvertebral fracture risk reduction) along with emerging new therapeutic agents, calcitonin has been relegated to a second- or third-line agent for osteoporosis prevention and treatment.

\section{Bisphosphonates}

Bisphosphonates are potent inhibitors of bone resorption and fractures when administered orally or by intravenous infusion [99]. Variations in the structure of the amino side chains of these drugs affect their pharmacological activity. All oral bisphosphonates are poorly absorbed, with bioavailability of less than $1 \%$. These agents bind tightly to hydroxyapatite crystals of bone, where they have a variable but generally long skeletal retention (approximately 10 years for alendronate). Over prolonged administration, a regional paracrine effect of continuously deposited and recycled bisphosphonates may partially account for a lack of rapid loss of BMD gains at some, but not all, skeletal sites when these agents are discontinued [100-102]. The nitrogen-containing bisphosphonates (that is, alendronate, risedronate, and zolendronate) have variable affinity for bone and function as antiresorptive agents by variable enzyme inhibition, impairing cholesterol metabolism of the osteoclast and leading to cytoskeletal alterations and premature osteoclast cell death via apoptosis $[103,104]$.

As a class, oral bisphosphonates may lead to gastrointestinal (GI) intolerance, particularly at low pH [105]. Most reported Gl symptoms have been nonulcer dyspepsia, and in most clinical trials, there have not been significant differences between those exposed to bisphosphonates and those receiving placebo $[106,107]$. There have been rare reports of severe esophagitis [108] and case reports of esophageal cancer in patients taking oral bisphosphonates [109]. Some small studies suggest that Gl side effects may be fewer with risedronate than alendronate [110].

The most common bisphosphonates licensed and used internationally are alendronate, risedronate, ibandronate, and zoledronic acid. These drugs are used in osteoporosis, Paget disease, myositis ossificans progressiva, heterotopic ossification, multiple myeloma, other malignancies with bone metastasis, and hypercalcemia. Alendronate, risedronate, and zoledronic acid have all been shown to improve BMD among patients receiving glucocorticoids [111-114].

Alendronate was the first aminobisphosphonate approved by the US Food and Drug Administration for the treatment and prevention of osteoporosis. Postmenopausal women receiving $10 \mathrm{mg} /$ day of alendronate showed a lumbar spine BMD increase of $7 \%$ to nearly $9 \%$ over a 2 -year period $[115,116]$. Smaller, but still significant, changes were seen at the femoral neck and trochanter. In early postmenopausal women, $5 \mathrm{mg} /$ day of alendronate prevented the loss of BMD at the spine, hip, and total body [117]. In a separate study, the $5 \mathrm{mg} /$ day dose prevented bone loss to nearly the same extent as an estrogen-progestin combination (estrogen effect was $1 \%$ to $2 \%$ greater than $5 \mathrm{mg}$ ) [118]. Increases in spinal BMD with alendronate continue for up to 7 years of daily therapy [119]. Daily alendronate has a similar benefit and adequate tolerability even among older female residents of 
long-term care facilities [120]. A once-weekly preparation of alendronate has greatly exceeded daily administration based on BMD efficacy, improved ease of use, and tolerability that is equivalent to or better than daily therapy [121,122]. Among 2,027 older women with at least one prior vertebral fracture and low femoral neck BMD in the Fracture Intervention Trial (FIT), alendronate had significant $47 \%$ and $51 \%$ reductions in morphometric vertebral and hip fractures, respectively [123]. In FIT subjects without prevalent vertebral fractures, alendronate $10 \mathrm{mg}$ decreased radiographic vertebral fractures by 44\% [124]. A multinational study of alendronate similarly identified a $47 \%$ risk reduction for nonvertebral fractures [125]. A long-term extension to the FIT study found that, with the exception of clinical vertebral fractures, fracture risk reduction at other skeletal sites was statistically indistinguishable in those receiving 5 years on followed by 5 years off of alendronate versus a full 10 years of therapy [100]. Further preliminary evaluation of these data has revealed that women with a femoral neck BMD T score of -2.5 or below at the 5-year mark had a higher risk of subsequent fractures [126]. Thus, the decision about whether to stop therapy with alendronate after a finite period of time is a topic of current controversy and in need of additional scientific data. In addition to prior duration of therapy, past adherence to therapy informs the risk of subsequent fractures [127].

Combination approaches of bisphosphonates with either estrogen or SERMs have shown equivalent or better BMD than with either therapy alone [128,129], although concerns of oversuppression of bone remodeling and potential risk of inadequate repair of bone microdamage persist [130]. Alendronate can attenuate the loss of BMD seen after stopping hormone replacement therapy [131].

Alendronate clinical trials have shown no significant increases in serious adverse effects or significant $\mathrm{Gl}$ adverse effects between treatment groups and placebo [106,132]. In a study of glucocorticoid-induced osteoporosis, there was a small increase in nonserious upper $\mathrm{Gl}$ adverse effects in those taking $10 \mathrm{mg}$ but not $5 \mathrm{mg}$ or placebo [111]. Results of bone histomorphometry indicate that alendronate decreases bone turnover in a dose-dependent manner but does not impair mineralization $[121,133,134]$.

Risedronate is a pyridinyl bisphosphonate that increases bone mass and prevents fractures [135]. In separate US [136] and multinational [137] VERT (Vertebral Efficacy with Risedronate Therapy) studies, 1,226 and 2,458 postmenopausal women with at least one prior vertebral fracture were treated with $5 \mathrm{mg}$ of risedronate. Women receiving risedronate experienced significantly fewer new vertebral (41\% US and 49\% multinational) and nonvertebral (39\% and 33\% reduction, respectively) fractures over a 3-year period [136]. In the Hip Intervention Program study, risedronate $5 \mathrm{mg}$ significantly reduced hip fractures among women with confirmed low bone mass but not among those selected primarily on the basis of fall risks without documented osteoporosis [138]. Similar to alendronate, combined treatment with risedronate and estrogen resulted in additive improvement in BMD and further reduction in bone turnover [139]. Although the increases in BMD seen with risedronate were more modest compared with those of alendronate in one head-to-head comparator study [140], a fairly similar fracture effectiveness is believed to be due in part to the decrease in bone resorption, as evidenced by significant suppression of biochemical markers [141,142]. Risedronate is taken daily, weekly, or (more recently) monthly and is generally well tolerated, with no significant differences in upper $\mathrm{Gl}$ adverse events between those receiving placebo and risedronate $[136,143]$.

Ibrandronate either orally (daily or monthly schedules) or intravenously successfully reduced markers of bone turnover, increased BMD [144,145], and reduced fractures of the vertebra (relative risk reduction $[R R R]=52 \%$ ) [146]. Secondary analyses of persons in ibandronate studies with initial BMD at or below -3.0 showed that ibandronate had a protective effect on hip fracture risk reduction as well.

Zolendronic acid (zolendronate) is administered as a yearly intravenous infusion and significantly reduced both vertebral $(\mathrm{RRR}=70 \%)$ and hip $(\mathrm{RRR}=41 \%)$ fractures in a large multinational study [147]. A subsequent study examined women and men who had experienced a prior hip fracture and showed a significant reduction in subsequent clinical fractures along with a reduction in mortality [148]. Side effects may include an acute-phase response with myalgias and flu-like symptoms in $10 \%$ to $15 \%$ of patients receiving their first dose. These symptoms most commonly resolve within several days and are attenuated with acetaminophen, prior oral bisphosphonates, and repeated doses of the intravenous therapy. Patients receiving intravenous zoledronic acid must have adequate renal function (creatinine clearance of greater than $30 \mathrm{~mL} /$ minute) prior to getting this agent.

On the basis of largely uncontrolled reports of osteonecrosis of the jaw and newer questions about atypical femoral fractures, there is increasing scrutiny of particularly longerterm therapy with bisphosphonates as a class [149]. Osteonecrosis of the jaw has been reported in an estimated $2 \%$ of cancer patients receiving higher doses of predominately intravenous bisphosphonates for patients with malignancies in particular [150]. Cases also have been described in patients receiving bisphosphonates for osteoporosis. Although mechanisms are not confirmed for these two adverse outcomes, if a relationship is supported by further studies, this will have further impact on the idea of a 'drug holiday' [151].

In summary, there have been a large number of studies documenting the efficacy of several bisphosphonates in terms of BMD gains and, of more importance, with regard to 
reduction of both vertebral and nonvertebral fractures. As a class, bisphosphonates are the most efficacious antiresorptive agents currently available for bone. Despite a significant duration of worldwide use of bisphosphonates, a number of questions such as the necessary duration of therapy, long-term safety, and use among women of childbearing potential as well as among children remain [152].

\section{Parathyroid hormone}

When bone is exposed to elevated PTH levels continuously (e.g., hyperparathyroidism) it acts in a catabolic fashion. In contrast, exogenously administered intermittent PTH is anabolic stimulating skeletal remodeling and raising BMD both in rodent models and in human studies [153,154]. PTH (residues 1 to 34 ) (teriparatide) significantly decreased the risk of vertebral (65\% risk reduction in those on $20 \mu \mathrm{g} /$ day) and nonvertebral fractures and increased BMD at all sites investigated, except for the radial shaft [155]. As a potential explanation for initial decreases in cortical bone density at sites such as the wrist, PTH initially increases intracortical porosity. It also leads to periosteal new bone formation and increases cross-sectional area, potentially increasing cortical bone strength $[156,157]$. Teriparatide increases BMD in the spine of men by nearly $6 \%$ [158]. There is an enhanced effect on bone mass when PTH is sequentially followed by alendronate [159] or estrogen [160]. When PTH is compared directly with alendronate, there is a greater BMD increase seen with PTH in postmenopausal [161] as well as glucocorticoid-associated [162] osteoporosis. Although BMD increases with PTH occur even in the presence of potent antiresorptive agents such as alendronate [163], antecedent oral bisphosphonates started concurrently with PTH may attenuate bone mass improvement seen with PTH $[164,165]$. PTH administered subcutaneously once a day has been associated with asymptomatic hypercalcemia, occasional nausea, and headache. Clinical trials of teriparatide were terminated early by the finding of osteosarcoma in Fisher rats [155]. Selective parathyroid receptor agonists and antagonists are under investigation and may play a future role in osteoporosis [166]. Due in part to the development of osteosarcoma in Fisher rats in the initial fracture trials (leading to their premature discontinuation), teriparatide at $20 \mu \mathrm{g} /$ day is recommended for only a 24-month administration. It is used most commonly in adults with severe osteoporosis, many of whom have had fractures while on other antiosteoporotic agents or have had intolerance to bisphosphonates.

\section{Strontium ranelate}

Daily intake of strontium ranelate has been shown to reduce the risk of vertebral and nonvertebral fractures in postmenopausal women with osteoporosis or a prevalent vertebral fracture or both. In a post hoc analysis in women over 74 years old with low BMD at the femoral neck, it reduces the risk of hip fractures [167,168]. Fracture reduction was still found after 5 years of treatment [169]. In a post hoc analysis in women older than 80 years, strontium ranelate reduced the risk of vertebral and nonvertebral fractures [170]. Strontium ranelate prevented quality-of-life impairment in postmenopausal women with established vertebral osteoporosis [171].

\section{Examples of new osteoporosis targets and new mechanisms of action Denosumab}

The discovery of the receptor activator of the nuclear factorkappa B ligand RANKL/RANK/osteoprotegerin (OPG) pathway has opened new ways to target osteoclastic bone resorption. Clinical trials indicate that denosumab, a RANKLspecific recombinant humanized monoclonal antibody, is effective in suppressing bone resorption, resulting in an increase in BMD in postmenopausal women with low BMD [172-175]. The effect of denosumab on BMD and markers of bone remodeling was more pronounced than with weekly alendronate [176]. The effects on fracture reduction in postmenopausal osteoporosis are awaited from the recently finished FREEDOM (Fracture REduction Evaluation of Denosumab in Osteoporosis Every 6 Months) study of nearly 8,000 women [177]. As compared with placebo, denosumab reduced the risk of new radiographic vertebral fracture by $68 \%$, with a cumulative incidence of $2.3 \%$ in the denosumab group versus $7.2 \%$ in the placebo group (risk ratio $0.32,95 \%$ $\mathrm{Cl} 0.26$ to $0.41 ; P<0.001)$. Denosumab significantly reduced the risk of hip fracture by $40 \%$ and also reduced significantly the risk of nonvertebral fracture by $20 \%$. There was no increase in the risk of cancer, infection, cardiovascular disease, delayed fracture healing, or hypocalcemia, and there were no cases of osteonecrosis of the jaw.

In clinical trials with denosumab, overall adverse events were similar to placebo or comparators, indicating a favorable safety profile in these diseases, which are, up until now, available up to 4 years. Since the RANKL/RANK/OPG pathway is involved in the development of the immune system, data on long-term safety, particularly with respect to bacterial infection and neoplasms, will be needed [172-176,178].

\section{Catepsin $\mathrm{K}$ inhibition}

Cathepsin $\mathrm{K}$ is the most abundant cysteine protease expressed in the osteoclast and is believed to be instrumental in the bone matrix degradation necessary for bone resorption. Cathepsin $\mathrm{K}$ inhibitors represent a novel target for developing agents to treat osteoporosis and other disorders characterized by increased bone resorption [179].

\section{Antisclerostin antibodies}

The discovery that the Wnt signaling is a major pathway in osteoblast activity has resulted in a revolution in our understanding of the molecular mechanisms that are involved in bone formation. Preclinical studies have shown that sclerostin has a pivotal role as a negative regulator of bone formation in the aging skeleton and, furthermore, suggest that 
antibody-mediated inhibition of sclerostin represents a promising new therapeutic approach for the anabolic treatment of bone-related disorders, such as postmenopausal osteoporosis [180].

\section{Summary}

In the past decade, we have witnessed a veritable revolution in osteoporosis diagnosis and therapeutics. Much of the success achieved has been motivated by an enhanced understanding of basic bone biology, a topic reviewed in a recent publication in the Arthritis Research \& Therapy anniversary series. While bone density maintains great respect as one of the most valid and reliable measures of fracture risk, a renewed appreciation for the importance of other risk factors has led to new interest in AR models such as FRAX. New imaging approaches, including lateral VFA, have been added to the diagnostic armamentarium of bone health evaluation in an effort to identify fractures earlier. There is an increased appreciation of the severe consequences of prevalent fractures, not only of the hip but also of the much more common spine fractures. In particular, data substantiating the heightened risk of short-term re-fracture have increased the interest in secondary osteoporosis prevention. As international focus on osteoporosis has grown, accentuated diagnosis of alternate metabolic bone disorders has followed, and astute clinicians must be aware that there are many causes for low bone mass beyond osteoporosis. The use of sufficient calcium and attention to adequate vitamin $D$ provide a necessary but often insufficient starting place for osteoporosis prevention and treatment. Aminobisphosphonates, taken orally or intravenously, have become the international mainstay of osteoporosis therapy. Questions exist about the very-long-term safety and the potential need for a drug holiday with some, if not all, of these compounds, despite their common use. Alternate therapeutic approaches that target suppression of bone resorption include historical use of sex steroids, SERMs, and now, less commonly, nasal calcitonin analogs. The mechanism of fracture reduction with daily strontium ranelate needs further study. Teriparatide is the first anabolic agent licensed for osteoporosis treatment

\section{The Scientific Basis
of Rheumatology:}

This article is part of a special collection of reviews, The Scientific Basis of Rheumatology: A Decade of Progress, published to mark Arthritis Research \& Therapy's 10th anniversary.

Other articles in this series can be found at: http://arthritis-research.com/sbr but it must be given as a daily subcutaneous injection and used for a defined period of time. Therapeutic approaches on the horizon include biologic agents targeting RANKL, antibodies to sclerositin (a natural inhibitor of Wnt-mediated bone formation), and approaches to inhibit proteolytic enzymes such as catepsin K. While the past decade and a half has been a very exciting time in clinical osteoporosis care, the next decade should offer even greater promise for further improving our diagnostic and treatment approaches.

\section{Competing interests}

KGS is a consultant, speaker or research grant recipient for Amgen, Lilly, Merck, Novartis, Proctor and Gamble, and Sanofi-Aventis. PG declares that they have no competing interests.

\section{References}

1. van Helden S, van Geel AC, Geusens PP, Kessels A, Nieuwenhuijzen Kruseman AC, Brink PR: Bone and fall-related fracture risks in women and men with a recent clinical fracture. $J$ Bone Joint Surg Am 2008, 90:241-248.

2. Kanis JA, Oden $A$, Johansson $H$, Borgstrom $F$, Strom $O$, McCloskey E: FRAX((R)) and its applications to clinical practice. Bone 2009, 44:734-743.

3. FRAX - WHO Fracture Risk Assessment Tool [http://www.shef. ac.uk/FRAX]

4. National Osteoporosis Foundation - Clinician's Guide to Prevention and Treatment of Osteoporosis [http://www.nof.org/ professionals/Clinicians_Guide.htm].

5. Kanis JA, McCloskey EV, Johansson H, Strom O, Borgstrom F, Oden A: Case finding for the management of osteoporosis with FRAX-assessment and intervention thresholds for the UK. Osteoporos Int 2008, 19:1395-1408.

6. Lippuner K, Johansson H, Kanis JA, Rizzoli R: FRAX(R) assessment of osteoporotic fracture probability in Switzerland. Osteoporos Int 2009 Jun 11. [Epub ahead of print].

7. McCloskey EV, Johansson H, Oden A, Vasireddy S, Kayan K, Pande K, Jalava T, Kanis JA: Ten-year fracture probability identifies women who will benefit from clodronate therapy-additional results from a double-blind, placebo-controlled randomised study. Osteoporos Int 2009, 20:811-817.

8. van Staa TP, Geusens P, Pols HA, de Laet C, Leufkens HG, Cooper $\mathrm{C}$ : A simple score for estimating the long-term risk of fracture in patients using oral glucocorticoids. QJM 2005, 98: 191-198.

9. van Geel TA, van Helden S, Geusens PP, Winkens B, Dinant GJ: Clinical subsequent fractures cluster in time after first fractures. Ann Rheum Dis 2009, 68:99-102.

10. Center JR, Bliuc D, Nguyen TV, Eisman JA: Risk of subsequent fracture after low-trauma fracture in men and women. JAMA 2007, 297:387-394.

11. van Geel AC, Geusens PP, Nagtzaam IF, Schreurs CM, van der Voort DJ, Rinkens PE, Kester AD, Dinant GJ: Timing and risk factors for clinical fractures among postmenopausal women: a 5-year prospective study. BMC Med 2006, 4:24.

12. van Helden S, Cals J, Kessels F, Brink P, Dinant GJ, Geusens P: Risk of new clinical fractures within 2 years following a fracture. Osteoporos Int 2006, 17:348-354.

13. Chevalley T, Hoffmeyer P, Bonjour JP, Rizzoli R: An osteoporosis clinical pathway for the medical management of patients with low-trauma fracture. Osteoporos Int 2002, 13:450-455.

14. Gallacher SJ, Gallagher AP, McQuillian C, Mitchell PJ, Dixon T: The prevalence of vertebral fracture amongst patients presenting with non-vertebral fractures. Osteoporos Int 2007, 18: 185-192.

15. Geusens PP, Roux CH, Reid DM, Lems WF, Adami S, Adachi JD, Sambrook PN, Saag KG, Lane NE, Hochberg MC: Drug Insight: choosing a drug treatment strategy for women with osteoporosis-an evidence-based clinical perspective. Nat Clin Pract Rheumatol 2008, 4:240-248.

16. Bliuc D, Nguyen ND, Milch VE, Nguyen TV, Eisman JA, Center JR: 
Mortality risk associated with low-trauma osteoporotic fracture and subsequent fracture in men and women. JAMA 2009, 301:513-521.

17. Sambrook P, Cooper C: Osteoporosis. Lancet 2006, 367:20102018.

18. Lems WF: Clinical relevance of vertebral fractures. Ann Rheum Dis 2007, 66:2-4.

19. Schousboe JT, Vokes T, Broy SB, Ferrar L, McKiernan F, Roux C, Binkley N: Vertebral Fracture Assessment: the 2007 ISCD Official Positions. J Clin Densitom 2008, 11:92-108.

20. Netelenbos JC, Lems WF, Geusens PP, Verhaar HJ, Boermans AJ, Boomsma MM, Mulder PG, Papapoulos SE: Spine radiographs to improve the identification of women at high risk for fractures. Osteoporos Int 2009, 20:1347-1352.

21. Tannenbaum C, Clark J, Schwartzman K, Wallenstein S, Lapinski $\mathrm{R}$, Meier D, Luckey M: Yield of laboratory testing to identify secondary contributors to osteoporosis in otherwise healthy women. J Clin Endocrinol Metab 2002, 87:4431-4437.

22. Dumitrescu $B$, van Helden $S$, ten Broeke $R$, NieuwenhuijzenKruseman A, Wyers C, Udrea G, van der Linden S, Geusens P: Evaluation of patients with a recent clinical fracture and osteoporosis, a multidisciplinary approach. BMC Musculoskelet Disord 2008, 9:109.

23. Bone Health and Osteoporosis: A Report of the Surgeon General [http://www.surgeongeneral.gov/library/bonehealth].

24. Kuchuk NO, van Schoor NM, Pluijm SM, Chines A, Lips P: Vitamin D status, parathyroid function, bone turnover, and BMD in postmenopausal women with osteoporosis: global perspective. J Bone Miner Res 2009, 24:693-701.

25. Pieper CF, Colon-Emeric C, Caminis J, Betchyk K, Zhang J, Janning C, Shostak J, LeBoff MS, Heaney RR, Lyles KW: Distribution and correlates of serum 25-hydroxyvitamin D levels in a sample of patients with hip fracture. Am J Geriatr Pharmacother 2007, 5:335-340.

26. Cauley JA, Lacroix AZ, Wu L, Horwitz M, Danielson ME, Bauer DC, Lee JS, Jackson RD, Robbins JA, Wu C, Stanczyk FZ, LeBoff MS, Wactawski-Wende J, Sarto G, Ockene J, Cummings SR: Serum 25-hydroxyvitamin $D$ concentrations and risk for hip fractures. Ann Intern Med 2008, 149:242-250.

27. Bischoff-Ferrari HA, Willett WC, Wong JB, Giovannucci E, Dietrich T, Dawson-Hughes B: Fracture prevention with vitamin D supplementation: a meta-analysis of randomized controlled trials. JAMA 2005, 293:2257-2264.

28. Bischoff-Ferrari HA, Dawson-Hughes B, Willett WC, Staehelin HB, Bazemore MG, Zee RY, Wong JB: Effect of Vitamin D on falls: a meta-analysis. JAMA 2004, 291:1999-2006.

29. Izaks GJ: Fracture prevention with vitamin $D$ supplementation: considering the inconsistent results. BMC Musculoskelet Disord 2007, 8:26.

30. Avenell A, Gillespie WJ, Gillespie LD, O'Connell D: Vitamin D and vitamin $D$ analogues for preventing fractures associated with involutional and post-menopausal osteoporosis. Cochrane Database Syst Rev 2009, (2):CD000227.

31. Heaney RP: Vitamin D: criteria for safety and efficacy. Nutr Rev 2008, 66 (10 Suppl 2):S178-181.

32. Bischoff-Ferrari HA: How to select the doses of vitamin D in the management of osteoporosis. Osteoporos Int 2007, 18: 401-407.

33. Dawson-Hughes $B$ : The role of vitamin $D$ in fracture prevention. IBMS BoneKEy 2005, 2:6-10.

34. Boonen $S$, Vanderschueren $D$, Haentjens $P$, Lips $P$ : Calcium and vitamin $\mathrm{D}$ in the prevention and treatment of osteoporosis - a clinical update. J Intern Med 2006, 259:539-552.

35. Kanis JA, Johansson $H$, Oden A, De Laet $C$, Johnell O, Eisman JA, Mc Closkey E, Mellstrom D, Pols H, Reeve J, Silman A, Tenenhouse A: A meta-analysis of milk intake and fracture risk: low utility for case finding. Osteoporos Int 2005, 16:799-804.

36. Boonen S, Lips P, Bouillon R, Bischoff-Ferrari HA, Vanderschueren D, Haentjens $P$ : Need for additional calcium to reduce the risk of hip fracture with vitamin d supplementation: evidence from a comparative metaanalysis of randomized controlled trials. J Clin Endocrinol Metab 2007, 92: 1415-1423.

37. Bolland MJ, Barber PA, Doughty RN, Mason B, Horne A, Ames R, Gamble GD, Grey A, Reid IR: Vascular events in healthy older women receiving calcium supplementation: randomised controlled trial. $B M J$ 2008, 336:262-266.
38. Reid IR, Ames R, Mason B, Reid HE Bacon CJ, Bolland MJ, Gamble GD, Grey A, Horne A: Randomized controlled trial of calcium supplementation in healthy, nonosteoporotic, older men. Arch Intern Med 2008, 168:2276-2282.

39. Andrews N: Calcium supplementation and vascular disease: a legitimate new worry? IBMS BoneKEy 2008, 5:124-129.

40. Roux C, Bischoff-Ferrari HA, Papapoulos SE, de Papp AE, West $J A$, Bouillon R: New insights into the role of vitamin $D$ and calcium in osteoporosis management: an expert roundtable discussion. Curr Med Res Opin 2008, 24:1363-1370.

41. Heaney RP: The Vitamin D requirement in health and disease. J Steroid Biochem Mol Biol 2005, 97:13-19.

42. Cranney A, Weiler HA, O'Donnell S, Puil L: Summary of evidence-based review on vitamin $D$ efficacy and safety in relation to bone health. Am J Clin Nutr 2008, 88:513S-519S.

43. Sabbagh $\mathrm{Z}$, Vatanparast $\mathrm{H}$ : Is calcium supplementation a risk factor for cardiovascular diseases in older women? Nutr Rev 2009, 67:105-108.

44. Kaufman JM, Vermeulen A: The decline of androgen levels in elderly men and its clinical and therapeutic implications. Endocr Rev 2005, 26:833-876.

45. Saad F, Adachi JD, Brown JP, Canning LA, Gelmon KA, Josse $\mathrm{RG}$, Pritchard $\mathrm{KI}$ : Cancer treatment-induced bone loss in breast and prostate cancer. J Clin Oncol 2008, 26:5465-5476.

46. Gillespie LD, Gillespie WJ, Robertson MC, Lamb SE, Cumming $\mathrm{RG}$, Rowe $\mathrm{BH}$ : Interventions for preventing falls in elderly people. Cochrane Database Syst Rev 2009, (2):CD000340.

47. Gillespie LD, Robertson MC, Gillespie WJ, Lamb SE, Gates S, Cumming RG, Rowe $\mathrm{BH}$ : Interventions for preventing falls in older people living in the community. Cochrane Database Syst Rev 2009, (2):CD007146.

48. Parker MJ, Gillespie LD, Gillespie WJ: Hip protectors for preventing hip fractures in the elderly. Cochrane Database Syst Rev 2005, (4):CD001255.

49. Warnke A, Meyer G, Bender R, Muhlhauser I: Predictors of adherence to the use of hip protectors in nursing home residents. J Am Geriatr Soc 2004, 52:340-345.

50. Siris ES, Bilezikian JP, Rubin MR, Black DM, Bockman RS, Bone HG, Hochberg MC, McClung MR, Schnitzer TJ: Pins and plaster aren't enough: a call for the evaluation and treatment of patients with osteoporotic fractures. J Clin Endocrinol Metab 2003, 88:3482-3486.

51. Tosteson AN, Grove MR, Hammond CS, Moncur MM, Ray GT, Hebert GM, Pressman AR, Ettinger B: Early discontinuation of treatment for osteoporosis. Am J Med 2003, 115:209-216.

52. Cauley JA, Seeley DG, Ensrud K, Ettinger B, Black D, Cummings SR: Estrogen replacement therapy and fractures in older women. Study of Osteoporotic Fractures Research Group. Ann Intern Med 1995, 122:9-16.

53. Kanis JA, Johnell O, Gullberg B, Allander E, Dilsen G, Gennari C, Lopes Vaz AA, Lyritis GP, Mazzuoli G, Miravet L, Passeri M, Cano RP, Rapado A, Ribot C: Evidence for efficacy of drugs affecting bone metabolism in preventing hip fracture. BMJ 1992, 305: 1124-1128.

54. Paganini-Hill A, Ross RK, Gerkins VR, Henderson BE, Arthur M, Mack TM: Menopausal estrogen therapy and hip fractures. Ann Intern Med 1981, 95:28-31.

55. Weiss NS, Ure CL, Ballard JH, Williams AR, Daling JR: Decreased risks of fractures of the hip and lower forearm with postmenopausal use of estrogen. N Engl J Med 1980, 303:1195-1198

56. Rossouw JE, Anderson GL, Prentice RL, LaCroix AZ, Kooperberg C, Stefanick ML, Jackson RD, Beresford SA, Howard BV, Johnson KC, Kotchen JM, Ockene J; Writing Group for the Women's Health Initiative Investigators: Risks and benefits of estrogen plus progestin in healthy postmenopausal women: principal results from the Women's Health Initiative Randomized Controlled Trial. JAMA 2002, 288:321-333.

57. The Women's Health Initiative Steering C: Effects of conjugated equine estrogen in postmenopausal women with hysterectomy: the Women's Health Initiative Randomized Controlled Trial. JAMA 2004, 291:1701-1712.

58. Binder EF, Williams DB, Schechtman KB, Jeffe DB, Kohrt WM: Effects of hormone replacement therapy on serum lipids in elderly women: a randomized, placebo-controlled trial. Ann Intern Med 2001, 134:754-760.

59. Walsh BW, Schiff I, Rosner B, Greenberg L, Ravnikar V, Sacks 
FM: Effects of postmenopausal estrogen replacement on the concentrations and metabolism of plasma lipoproteins. $N$ Engl J Med 1991, 325:1196-1204.

60. Grodstein F, Chen J, Pollen DA, Albert MS, Wilson RS, Folstein MF, Evans DA, Stampfer MJ: Postmenopausal hormone therapy and cognitive function in healthy older women. $J A m$ Geriatr Soc 2000, 48:746-752.

61. Grodstein F, Stampfer MJ, Colditz GA, Willett WC, Manson JE, Joffe M, Rosner B, Fuchs C, Hankinson SE, Hunter DJ, Hennekens $\mathrm{CH}$, Speizer FE: Postmenopausal hormone therapy and mortality. N Engl J Med 1997, 336:1769-1775.

62. Hulley S, Grady D, Bush T, Furberg C, Herrington D, Riggs B, Vittinghoff $E$ : Randomized trial of estrogen plus progestin for secondary prevention of coronary heart disease in postmenopausal women. Heart and Estrogen/progestin Replacement Study (HERS) Research Group. JAMA 1998, 280: 605-613.

63. Newton KM, LaCroix AZ, McKnight B, Knopp RH, Siscovick DS, Heckbert SR, Weiss NS: Estrogen replacement therapy and prognosis after first myocardial infarction. Am J Epidemiol 1997, 145:269-277.

64. O'Keefe JH Jr., Kim SC, Hall RR, Cochran VC, Lawhorn SL, McCallister BD: Estrogen replacement therapy after coronary angioplasty in women. $J$ Am Coll Cardiol 1997, 29:1-5.

65. Sullivan JM, El-Zeky F, Vander Zwaag R, Ramanathan KB: Effect on survival of estrogen replacement therapy after coronary artery bypass grafting. Am J Cardiol 1997, 79:847-850.

66. Barrett-Connor E: Postmenopausal estrogen and prevention bias. Ann Intern Med 1991, 115:455-456.

67. Grodstein F, Stampfer MJ, Manson JE, Colditz GA, Willett WC, Rosner B, Speizer FE, Hennekens CH: Postmenopausal estrogen and progestin use and the risk of cardiovascular disease. N Engl J Med 1996, 335:453-461.

68. Grady D, Wenger NK, Herrington D, Khan S, Furberg C, Hunninghake $D$, Vittinghoff $E$, Hulley $S$ : Postmenopausal hormone therapy increases risk for venous thromboembolic disease: the Heart and Estrogen/progestin Replacement Study. Ann Intern Med 2000, 132:689-696.

69. Diamond TH, Champion B, Clark WA: Management of acute osteoporotic vertebral fractures: a nonrandomized trial comparing percutaneous vertebroplasty with conservative therapy. Am J Med 2003, 114:257-265.

70. Gapstur SM, Morrow M, Sellers TA: Hormone replacement therapy and risk of breast cancer with a favorable histology: results of the lowa Women's Health Study. JAMA 1999, 281: 2091-2097.

71. Stallard S, Litherland JC, Cordiner CM, Dobson HM, George WD, Mallon EA, Hole D: Effect of hormone replacement therapy on the pathological stage of breast cancer: population based, cross sectional study. BMJ 2000, 320:348-349.

72. Chen C-L, Weiss NS, Newcomb P, Barlow W, White E: Hormone replacement therapy in relation to breast cancer. JAMA 2002, 287:734-741.

73. Col NF, Eckman MH, Karas RH, Pauker SG, Goldberg RJ, Ross EM, Orr RK, Wong JB: Patient-specific decisions about hormone replacement therapy in postmenopausal women. JAMA 1997, 277:1140-1147.

74. Keating NL, Cleary PD, Rossi AS, Zaslavsky AM, Ayanian JZ: Use of hormone replacement therapy by postmenopausal women in the United States. Ann Intern Med 1999, 130:545-553.

75. Lindsay R, Gallagher JC, Kleerekoper M, Pickar JH: Effect of lower doses of conjugated equine estrogens with and without medroxyprogesterone acetate on bone in early postmenopausal women. JAMA 2002, 287:2668-2676.

76. Prestwood KM, Kenny AM, Kleppinger A, Kulldorff M: Ultralowdose micronized $17 \mathrm{~b}$-estradiol and bone density and bone metabolism in older women: a randomized controlled trial. JAMA 2003, 290:1042-1048.

77. Manson JE, Martin KA: Postmenopausal hormone-replacement therapy. N Engl J Med 2001, 345:34-40.

78. Nelson H, Helfand M, Woolf S, Allan J: Screening for postmenopausal osteoporosis: A review of the evidence for the U.S. preventive services task force. Ann Intern Med 2002, 137: 529-541.

79. Khovidhunkit $W$, Shoback DM: Clinical effects of raloxifene hydrochloride in women. Ann Intern Med 1999, 130:431-439.

80. Ettinger B, Black DM, Mitlak BH, Knickerbocker RK, Nickelsen T,
Genant HK, Christiansen C, Delmas PD, Zanchetta JR Stakkestad J, Glüer CC, Krueger K, Cohen FJ, Eckert S, Ensrud KE, Avioli LV, Lips P, Cummings SR: Reduction of vertebral fracture risk in postmenopausal women with osteoporosis treated with raloxifene: results from a 3-year randomized clinical trial. Multiple Outcomes of Raloxifene Evaluation (MORE) Investigators. JAMA 1999, 282:637-645.

81. Riggs BL, Melton III LJ: Bone turnover matters: the raloxifene treatment paradox of dramatic decreases in vertebral fractures without commensurate increases in bone density. $J$ Bone Min Res 2002, 17:11-14.

82. Sarkar S, Mitlak BH, Wong M, Black DM, Harper KD: Relationships between bone mineral density and incident vertebral fracture risk with raloxifene therapy. J Bone Min Res 2002, 17: $1-10$.

83. Cauley JA, Norton L, Lippman ME, Eckert S, Krueger KA, Purdie DW, Farrerons J, Karasik A, Mellstrom D, Ng KW, Stepan JJ, Powles TJ, Morrow M, Costa A, Silfen SL, Walls EL, Schmitt H, Muchmore DB, Jordan VC, Ste-Marie LG: Continued breast cancer risk reduction in postmenopausal women treated with raloxifene: 4-year results from the MORE trial. Breast Cancer Res Treat 2001, 65:125-134.

84. Cummings SR, Eckert S, Krueger KA, Grady D, Powles TJ, Cauley JA, Norton L, Nickelsen T, Bjarnason NH, Morrow M, Lippman ME, Black D, Glusman JE, Costa A, Jordan VC: The effect of raloxifene on risk of breast cancer in postmenopausal women: results from the MORE randomized trial. Multiple Outcomes of Raloxifene Evaluation. JAMA 1999, 281:2189-2197.

85. Cummings SR, Duong T, Kenyon E, Cauley JA, Whitehead M, Krueger KA; Multiple Outcomes of Raloxifene Evaluation (MORE) Trial: Serum estradiol level and risk of breast cancer during treatment with raloxifene. JAMA 2002, 287:216-220.

86. Grady D, Cauley JA, Geiger MJ, Kornitzer M, Mosca L, Collins P Wenger NK, Song J, Mershon J, Barrett-Connor E; Raloxifene Use for The Heart Trial Investigators: Reduced incidence of invasive breast cancer with raloxifene among women at increased coronary risk. J Natl Cancer Inst 2008, 100:854-861.

87. Silverman SL, Christiansen C, Genant HK, Vukicevic S, Zanchetta JR, de Villiers TJ, Constantine GD, Chines AA: Efficacy of bazedoxifene in reducing new vertebral fracture risk in postmenopausal women with osteoporosis: results from a 3-year, randomized, placebo-, and active-controlled clinical trial. $J$ Bone Miner Res 2008, 23:1923-1934.

88. Cummings SR, Eastell R, Ensrud K, Reid DM, Vukicevic S, LaCroix A, Sriram U, Thompson D, Thompson JR, Delmas PD: The effects of lasofoxifene on fractures and breast cancer: 3year results from the PEARL trial [abstract]. $J$ Bone Miner Res 2008, 1288:S81.

89. Ljunghall $S$, Gärdsell $P$, Johnell $O$, Larsson $K$, Lindh $E$, Obrant $K$, Sernbo I: Synthetic human calcitonin in postmenopausal osteoporosis: a placebo-controlled, double-blind study. Calcif Tissue Int 1991, 49:17-19.

90. Maclntyre I, Stevenson JC, Whitehead MI, Wimalawansa SJ, Banks LM, Healy MJ: Calcitonin for prevention of postmenopausal bone loss. Lancet 1988, 1:900-902.

91. Mazzuoli GF, Passeri M, Gennari C, Minisola S, Antonelli R, Valtorta C, Palummeri E, Cervellin GF, Gonnelli S, Francini G: Effects of salmon calcitonin in postmenopausal osteoporosis: a controlled double-blind clinical study. Calcif Tissue Int 1986 38:3-8.

92. Ellerington MC, Hillard TC, Whitcroft SI, Marsh MS, Lees B, Banks LM, Whitehead MI, Stevenson JC: Intranasal salmon calcitonin for the prevention and treatment of postmenopausal osteoporosis. Calcif Tissue Int 1996, 59:6-11.

93. Overgaard K, Riis BJ, Christiansen C, Hansen MA: Effect of salcatonin given intranasally on early postmenopausal bone loss. BMJ 1989, 299:477-479.

94. Reginster JY, Deroisy R, Lecart MP, Sarlet N, Zegels B, Jupsin I, de Longueville M, Franchimont P: A double-blind, placebo-controlled, dose-finding trial of intermittent nasal salmon calcitonin for prevention of postmenopausal lumbar spine bone loss. Am J Med 1995, 98:452-458.

95. Thamsborg G, Storm TL, Sykulski R, Brinch E, Nielsen HK, Sorensen $\mathrm{OH}$ : Effect of different doses of nasal salmon calcitonin on bone mass. Calcif Tissue Int 1991, 48:302-307.

96. Nielsen NM, von der Recke P, Hansen MA, Overgaard K, Christiansen $C$ : Estimation of the effect of salmon calcitonin in 
established osteoporosis by biochemical bone markers. Calcif Tissue Int 1994, 55:8-11.

97. Chesnut $\mathrm{CH}$ 3rd, Silverman S, Andriano K, Genant H, Gimona A, Harris S, Kiel D, LeBoff M, Maricic M, Miller P, Moniz C, Peacock $M$, Richardson $P$, Watts $N$, Baylink $D$ : A randomized trial of nasal spray salmon calcitonin in postmenopausal women with established osteoporosis: the Prevent Recurrence of Osteoporotic Fractures Study. Am J Med 2000, 109:267-276.

98. Silverman SL, Chesnut C, Andriano K, Genant H, Gimona A, Maricic M, Stock J, Baylink D: Salmon calcitonin nasal spray (NSCT) reduces risk of vertebral fracture(s) (VF) in established osteoporosis and has continuous efficacy with prolonged treatment: accrued 5 year worldwide data of The PROOF Study [abstract]. J Bone Miner Res 1998, 23 (Suppl 5):S174.

99. Cummings SR, Nevitt MC: Non-skeletal determinants of fractures: the potential importance of the mechanics of falls. Study of Osteoporotic Fractures Research Group. Osteoporos Int 1994, 4 (Suppl 1):67-70.

100. Black DM, Schwartz AV, Ensrud KE, Cauley JA, Levis S, Quandt SA, Satterfield S, Wallace RB, Bauer DC, Palermo L, Wehren LE, Lombardi A, Santora AC, Cummings SR; FLEX Research Group: Effects of continuing or stopping alendronate after 5 years of treatment: the Fracture Intervention Trial Long-term Extension (FLEX): a randomized trial. JAMA 2006, 296:2927-2938.

101. Stock JL, Bell NH, Chesnut CH 3rd, Ensrud KE, Genant HK, Harris ST, McClung MR, Singer FR, Yood RA, Pryor-Tillotson S, Wei L, Santora AC 2nd: Increments in bone mineral density of the lumbar spine and hip and suppression of bone turnover are maintained after discontinuation of alendronate in postmenopausal women. Am J Med 1997, 103:291-297.

102. Rossini M, Gatti D, Zamberlan N, Braga V, Dorizzi R, Adami S: Long-term effects of a treatment course with oral alendronate of postmenopausal osteoporosis. J Bone Miner Res 1994, 9: 1833-1837.

103. Russell RG, Rogers MJ, Frith JC, Luckman SP, Coxon FP, Benford $\mathrm{HL}$, Croucher PI, Shipman C, Fleisch HA: The pharmacology of bisphosphonates and new insights into their mechanisms of action. J Bone Miner Res 1999, 14 (Suppl 2):53-65.

104. Rodan GA: Mechanisms of action of bisphosphonates. Annu Rev Pharmacol Toxicol 1998, 38:375-388.

105. Peter CP, Handt LK, Smith SM: Esophageal irritation due to alendronate sodium tablets: possible mechanisms. Dig Dis Sci 1998, 43:1998-2002.

106. Bauer DC, Black D, Ensrud K, Thompson D, Hochberg M, Nevitt $M$, Musliner T, Freedholm D: Upper gastrointestinal tract safety profile of alendronate: The Fracture Intervention Trial. Arch Intern Med 2000, 160:517-525.

107. Donahue JG, Chan KA, Andrade SE, Beck A, Boles M, Buist DS, Carey VJ, Chandler JM, Chase GA, Ettinger B, Fishman P, Goodman M, Guess HA, Gurwitz JH, LaCroix AZ, Levin TR, Platt R: Gastric and duodenal safety of daily alendronate. Arch Intern Med 2002, 162:936-942.

108. de Groen PC, Lubbe DF, Hirsch LJ, Daifotis A, Stephenson W, Freedholm D, Pryor-Tillotson S, Seleznick MJ, Pinkas H, Wang KK: Esophagitis associated with the use of alendronate. $N$ Engl J Med 1996, 335:1016-1021.

109. Wysowski DK: Reports of esophageal cancer with oral bisphosphonate use. N Engl J Med 2009, 360:89-90.

110. Lanza FL, Hunt RH, Thomson ABR, Provenza JM, Blank MA, for the Risedronate Endoscopy Study Group: Endoscopic comparison of esophageal and gastroduodenal effects of risedronate and alendronate in postmenopausal women. Gastroenterology 2000, 119:631-638.

111. Saag KG, Emkey R, Schnitzer TJ, Brown JP, Hawkins F, Goemaere S, Thamsborg G, Liberman UA, Delmas PD, Malice MP, Czachur M, Daifotis AG: Alendronate for the prevention and treatment of glucocorticoid-induced osteoporosis. Glucocorticoid-Induced Osteoporosis Intervention Study Group. N Engl J Med 1998, 339:292-299.

112. Cohen S, Levy RM, Keller M, Boling E, Emkey RD, Greenwald M, Zizic TM, Wallach S, Sewell KL, Lukert BP, Axelrod DW, Chines AA: Risedronate therapy prevents corticosteroid-induced bone loss: a twelve-month, multicenter, randomized, doubleblind, placebo-controlled, parallel-group study. Arthritis Rheum 1999, 42:2309-2318.

113. Reid DM, Hughes RA, Laan RF, Sacco-Gibson NA, Wenderoth $\mathrm{DH}$, Adami S, Eusebio RA, Devogelaer JP: Efficacy and safety of daily risedronate in the treatment of corticosteroid-induced osteoporosis in men and women: a randomized trial. European Corticosteroid-Induced Osteoporosis Treatment Study. $J$ Bone Miner Res 2000, 15:1006-1013.

114. Reid DM, Devogelaer JP, Saag K, Roux C, Lau CS, Reginster JY, Papanastasiou P, Ferreira A, Hartl F, Fashola T, Mesenbrink P, Sambrook PN; HORIZON investigators: Zoledronic acid and risedronate in the prevention and treatment of glucocorticoidinduced osteoporosis (HORIZON): a multicentre, doubleblind, double-dummy, randomised controlled trial. Lancet 2009, 373:1253-1263.

115. Chesnut CH 3rd, McClung MR, Ensrud KE, Bell NH, Genant HK, Harris ST, Singer FR, Stock JL, Yood RA, Delmas PD: Alendronate treatment of the postmenopausal osteoporotic woman: effect of multiple dosages on bone mass and bone remodeling. Am J Med 1995, 99:144-152.

116. Liberman UA, Weiss SR, Bröll J, Minne HW, Quan H, Bell NH Rodriguez-Portales J, Downs RW Jr., Dequeker J, Favus M: Effect of oral alendronate on bone mineral density and the incidence of fractures in postmenopausal osteoporosis. The Alendronate Phase III Osteoporosis Treatment Study Group. N Engl J Med 1995, 333:1437-1443.

117. McClung $M$, Clemmesen B, Daifotis A, Gilchrist NL, Eisman J, Weinstein RS, Fuleihan G el-H, Reda C, Yates AJ, Ravn P: Alendronate prevents postmenopausal bone loss in women without osteoporosis. A double-blind, randomized, controlled trial. Alendronate Osteoporosis Prevention Study Group. Ann Intern Med 1998, 128:253-261.

118. Hosking D, Chilvers CE, Christiansen C, Ravn P, Wasnich R, Ross P, McClung M, Balske A, Thompson D, Daley M, Yates AJ: Prevention of bone loss with alendronate in postmenopausal women under 60 years of age. Early Postmenopausal Intervention Cohort Study Group. N Engl J Med 1998, 338:485492.

119. Tonino RP, Meunier PJ, Emkey R, Rodriguez-Portales JA, Menkes CJ, Wasnich RD, Bone HG, Santora AC, Wu M, Desai R, Ross PD: Skeletal benefits of alendronate: 7-year treatment of postmenopausal osteoporotic women. J Clin Endocrinol Metab 2000, 85:3109-3115.

120. Greenspan SL, Schneider DL, McClung MR, Miller PD, Schnitzer TJ, Bonin R, Smith ME, DeLucca P, Gormley GJ, Melton ME: Alendronate improves bone mineral density in elderly women with osteoporosis residing in long-term care facilities: a randomized, double-blind, placebo-controlled trial. Ann Intern Med 2002, 136:742-746.

121. Rizzoli R, Greenspan SL, Bone G 3rd, Schnitzer TJ, Watts NB, Adami S, Foldes AJ, Roux C, Levine MA, Uebelhart B, Santora AC 2nd, Kaur A, Peverly CA, Orloff JJ; Alendronate Once-Weekly Study Group: Two-year results of once-weekly administration of alendronate $70 \mathrm{mg}$ for the treatment of postmenopausal osteoporosis. J Bone Min Res 2002, 17:1988-1996.

122. Schnitzer T, Bone HG, Crepaldi G, Adami S, McClung M, Kiel D, Felsenberg D, Recker RR, Tonino RP, Roux C, Pinchera A, Foldes AJ, Greenspan SL, Levine MA, Emkey R, Santora AC 2nd, Kaur A, Thompson DE, Yates J, Orloff JJ: Therapeutic equivalence of alendronate $70 \mathrm{mg}$ once-weekly and alendronate $10 \mathrm{mg}$ daily in the treatment of osteoporosis. Aging (Milano) 2000, 12:112.

123. Black DM, Cummings SR, Karpf DB, Cauley JA, Thompson DE, Nevitt MC, Bauer DC, Genant HK, Haskell WL, Marcus R, Ott SM, Torner JC, Quandt SA, Reiss TF, Ensrud KE: Randomised trial of effect of alendronate on risk of fracture in women with existing vertebral fractures. Fracture Intervention Trial Research Group. Lancet 1996, 348:1535-1541.

124. Cummings SR, Black DM, Thompson DE, Applegate WB, BarrettConnor E, Musliner TA, Palermo L, Prineas R, Rubin SM, Scott JC, Vogt T, Wallace R, Yates AJ, LaCroix AZ: Effect of alendronate on risk of fracture in women with low bone density but without vertebral fractures: results from the Fracture Intervention Trial. JAMA 1998, 280:2077-2082.

125. Pols HA, Felsenberg D, Hanley DA, Stepán J, Muñoz-Torres M, Wilkin TJ, Qin-sheng G, Galich AM, Vandormael K, Yates AJ, Stych B: Multinational, placebo-controlled, randomized trial of the effects of alendronate on bone density and fracture risk in postmenopausal women with low bone mass: results of the FOSIT study. Fosamax International Trial Study Group. Osteoporos Int 1999, 9:461-468. 
126. Schwartz AV, Bauer DC, Cauley JA, Ensrud K, Palermo L, Wallace RB, Hochberg MC, Feldstein C, Lombardi A, Cummings SR, Black DM: Efficacy of continued alendronate for fractures in women without prevalent vertebral fracture: the FLEX Trial [abstract]. J Bone Min Res 2007, 22 (Suppl 1):S1057.

127. Curtis JR, Westfall AO, Cheng H, Delzell E, Saag KG: Risk of hip fracture after bisphosphonate discontinuation: implications for a drug holiday. Osteoporos Int 2008, 19:1613-1620.

128. Lindsay R, Cosman F, Lobo RA, Walsh BW, Harris ST, Reagan $\mathrm{JE}$, Liss CL, Melton ME, Byrnes CA: Addition of alendronate to ongoing hormone replacement therapy in the treatment of osteoporosis: a randomized, controlled clinical trial. J Clin Endocrinol Metab 1999, 84:3076-3081.

129. Greenspan SL, Resnick NM, Parker RA: Combination therapy with hormone replacement and alendronate for prevention of bone loss in elderly women. A randomized controlled trial. JAMA 2003, 289:2525-2533.

130. Ettinger B, Bilezikian JP: For osteoporosis, are two antiresorptive drugs better than one? J Clin Endocrinol Metab 2002, 87: 983-984.

131. Ascott-Evans BH, Guanabens N, Kivinen S, Stuckey BG, Magaril $\mathrm{CH}$, Vandormael K, Stych B, Melton ME: Alendronate prevents loss of bone density associated with discontinuation of hormone replacement therapy: a randomized controlled trial. Arch Intern Med 2003, 163:789-794.

132. Lowe CE, Depew WT, Vanner SJ, Paterson WG, Meddings JB: Upper gastrointestinal toxicity of alendronate. Am J Gastroenterol 2000, 95:634-640.

133. Balena R, Toolan BC, Shea M, Markatos A, Myers ER, Lee SC, Opas EE, Seedor JG, Klein H, Frankenfield D, Quartuccio H, Fioravanti C, Clair J, Brown E, Hayes WC, Rodan GA The effects of 2-year treatment with the aminobisphosphonate alendronate on bone metabolism, bone histomorphometry, and bone strength in ovariectomized nonhuman primates. J Clin Invest 1993, 92:2577-2586.

134. Chavassieux PM, Arlot ME, Reda C, Wei L, Yates AJ, Meunier PJ: Histomorphometric assessment of the long-term effects of alendronate on bone quality and remodeling in patients with osteoporosis. J Clin Invest 1997, 100:1475-1480.

135. Mortensen L, Charles P, Bekker PJ, Digennaro J, Johnston CC Jr.: Risedronate increases bone mass in an early postmenopausal population: two years of treatment plus one year of follow-up. J Clin Endocrinol Metab 1998, 83:396-402.

136. Harris ST, Watts NB, Genant HK, McKeever CD, Hangartner T, Keller M, Chesnut CH 3rd, Brown J, Eriksen EF, Hoseyni MS, Axelrod DW, Miller PD: Effects of risedronate treatment on vertebral and nonvertebral fractures in women with postmenopausal osteoporosis: a randomized controlled trial. Vertebral Efficacy With Risedronate Therapy (VERT) Study Group. JAMA 1999, 282:1344-1352.

137. Reginster J, Minne HW, Sorensen OH, Hooper M, Roux C, Brandi ML, Lund B, Ethgen D, Pack S, Roumagnac I, Eastell R: Randomized trial of the effects of risedronate on vertebral fractures in women with established postmenopausal osteoporosis. Vertebral Efficacy with Risedronate Therapy (VERT) Study Group. Osteoporos Int 2000, 11:83-91.

138. McClung MR, Geusens P, Miller PD, Zippel H, Bensen WG, Roux C, Adami S, Fogelman I, Diamond T, Eastell R, Meunier PJ, Reginster JY; Hip Intervention Program Study Group: Effect of risedronate on the risk of hip fracture in elderly women. $N$ Engl J Med 2001, 344:333-340.

139. Harris ST, Eriksen EF, Davidson M, Ettinger MP, Moffett Jr AH Jr., Baylink DJ, Crusan CE, Chines AA: Effect of combined risedronate and hormone replacement therapies on bone mineral density in postmenopausal women. $J$ Clin Endocrinol Metab 2001, 86:1890-1897.

140. Rosen CJ, Hochberg MC, Bonnick SL, McClung M, Miller P, Broy $S$, Kagan R, Chen E, Petruschke RA, Thompson DE, de Papp AE; Fosamax Actonel Comparison Trial Investigators: Treatment with once-weekly alendronate $\mathbf{7 0} \mathrm{mg}$ compared with once-weekly risedronate $35 \mathrm{mg}$ in women with postmenopausal osteoporosis: a randomized double-blind study. J Bone Miner Res 2005, 20:141-151.

141. Curtis JR, Westfall AO, Cheng H, Saag KG, Delzell E: RisedronatE and ALendronate Intervention over Three Years (REALITY): minimal differences in fracture risk reduction. Osteoporos Int 2009, 20:973-978.
142. Eastell R, Barton I, Hannon RA, Chines A, Garnero P, Delmas PD: Relationship of early changes in bone resorption to the reduction in fracture risk with risedronate. J Bone Min Res 2003, 18: 1051-1056.

143. Taggart $H$, Bolognese MA, Lindsay $R$, Ettinger MP, Mulder $H$, Josse RG, Roberts A, Zippel H, Adami S, Ernst TF, Stevens KP: Upper gastrointestinal tract safety of risedronate: a pooled analysis of 9 clinical trials. Mayo Clin Proc 2002, 77:262-270.

144. Riis BJ, Ise J, von Stein T, Bagger Y, Christiansen C: Ibandronate: a comparison of oral daily dosing versus intermittent dosing in postmenopausal osteoporosis. J Bone Min Res 2001, 16:1871-1878.

145. Schimmer RC, Bauss F: Effect of daily and intermittent use of ibandronate on bone mass and bone turnover in postmenopausal osteoporosis: a review of three phase II studies. Clin Ther 2003, 25:19-34.

146. Chesnut III CH, Skag A, Christiansen C, Recker R, Stakkestad JA, Hoiseth A, Felsenberg D, Huss H, Gilbride J, Schimmer RC Delmas PD; Oral Ibandronate Osteoporosis Vertebral Fracture Trial in North America and Europe (BONE): Effects of oral ibandronate administered daily or intermittently on fracture risk in postmenopausal osteoporosis. J Bone Miner Res 2004, 19:1241-1249.

147. Black DM, Delmas PD, Eastell R, Reid IR, Boonen S, Cauley JA, Cosman F, Lakatos P, Leung PC, Man Z, Mautalen C, Mesenbrink $\mathrm{P}, \mathrm{Hu} \mathrm{H}$, Caminis J, Tong K, Rosario-Jansen T, Krasnow J, Hue TF, Sellmeyer D, Eriksen EF, Cummings SR; HORIZON Pivotal Fracture Trial: Once-yearly zoledronic acid for treatment of postmenopausal osteoporosis. $N$ Engl J Med 2007, 356: 1809-1822.

148. Lyles KW, Colón-Emeric CS, Magaziner JS, Adachi JD, Pieper CF, Mautalen C, Hyldstrup L, Recknor C, Nordsletten L, Moore KA, Lavecchia C, Zhang J, Mesenbrink P, Hodgson PK, Abrams K Orloff JJ, Horowitz Z, Eriksen EF, Boonen S; for the HORIZON Recurrent Fracture Trial: Zoledronic acid in reducing clinical fracture and mortality after hip fracture. N Engl J Med 2007, 357:nihpa40967.

149. Lenart BA, Neviaser AS, Lyman S, Chang CC, Edobor-Osula F, Steele B, van der Meulen MC, Lorich DG, Lane JM: Association of low-energy femoral fractures with prolonged bisphosphonate use: a case control study. Osteoporos Int 2009, 20:13531362.

150. Hoff AO, Toth BB, Altundag K, Johnson MM, Warneke CL, Hu M, Nooka A, Sayegh G, Guarneri V, Desrouleaux K, Cui J, Adamus A, Gagel RF, Hortobagyi GN: Frequency and risk factors associated with osteonecrosis of the jaw in cancer patients treated with intravenous bisphosphonates. J Bone Miner Res 2008, 23:826-836.

151. Geusens P: Bisphosphonates for postmenopausal osteoporosis: determining duration of treatment. Curr Osteoporos Rep 2009, 7:12-17.

152. Whyte MP, Wenkert D, Clements KL, McAlister WH, Mumm S: Bisphosphonate-induced osteopetrosis. N Engl J Med 2003, 349:457-463.

153. Misof BM, Roschger P, Cosman F, Kurland ES, Tesch W, Messmer $P$, Dempster DW, Nieves J, Shane E, Fratzl $P$, Klaushofer K, Bilezikian J, Lindsay R: Effects of intermittent parathyroid hormone administration on bone mineralization density in iliac crest biopsies from patients with osteoporosis: a paired study before and after treatment. J Clin Endocrinol Metab 2003, 88:1150-1156.

154. Reginster JY, Taquet AN, Fraikin G, Gosset C, Zegels B: Parathyroid hormone in the treatment of involutional osteoporosis: back to the future. Osteoporos Int 1997, 7 (Suppl 3):S163-168.

155. Neer RM, Arnaud CD, Zanchetta JR, Prince R, Gaich GA, Reginster JY, Hodsman AB, Eriksen EF, Ish-Shalom S, Genant HK, Wang O, Mitlak BH: Effect of parathyroid hormone (1-34) on fractures and bone mineral density in postmenopausal women with osteoporosis. N Engl J Med 2001, 344:14341441

156. Parfitt AM: Parathyroid hormone and periosteal bone expansion. J Bone Min Res 2002, 17:1741-1743.

157. Zanchetta JR, Bogado CE, Ferretti JL, Wang O, Wilson MG, Sato M, Gaich GA, Dalsky GP, Myers SL: Effects of teriparatide [recombinant human parathyroid hormone (1-34)] on cortical bone in postmenopausal women with osteoporosis. J Bone Min Res 2003, 18:539-543. 
158. Orwoll ES, Scheele WH, Paul S, Adami S, Syversen U, DiezPerez A, Kaufman JM, Clancy AD, Gaich GA: The effect of teriparatide [human parathyroid hormone (1-34)] therapy on bone density in men with osteoporosis. J Bone Min Res 2003, 18:9-17.

159. Rittmaster RS, Bolognese M, Ettinger MP, Hanley DA, Hodsman $A B$, Kendler DL, Rosen $C J$ : Enhancement of bone mass in osteoporotic women with parathyroid hormone followed by alendronate. J Clin Endocrinol Metab 2000, 85:2129-2134.

160. Cosman F, Nieves J, Woelfert L, Formica C, Gordon S, Shen V, Lindsay R: Parathyroid hormone added to established hormone therapy: effects of vertebral fracture and maintenance of bone mass after parathyroid hormone withdrawal. $J$ Bone Min Res 2001, 16:925-931.

161. Body J-J, Gaich GA, Scheele WH, Kulkarni PM, Miller PD, Peretz A, Dore RK, Correa-Rotter R, Papaioannou A, Cumming DC, Hodsman AB: A randomized double-blind trial to compare the efficacy of teriparatide [recombinant human parathyroid hormone (1-34)] with alendronate in postmenopausal women with osteoporosis. J Clin Endocrinol Metab 2002, 87:45284535.

162. Saag KG, Shane E, Boonen S, Marín F, Donley DW, Taylor KA, Dalsky GP, Marcus R: Teriparatide or alendronate in glucocorticoid-induced osteoporosis. N Engl J Med 2007, 357:20282039.

163. Cosman F, Nieves J, Woelfert L, Shen V, Lindsay R: Alendronate does not block the anabolic effect of PTH in postmenopausal osteoporotic women. J Bone Miner Res 1998, 13:1051-1055.

164. Black DM, Greenspan SL, Ensrud KE, Palermo L, McGowan JA, Lang TF, Garnero P, Bouxsein ML, Bilezikian JP, Rosen CJ; PaTH Study Investigators: The effects of parathyroid hormone and alendronate alone or in combination in postmenopausal osteoporosis. N Engl J Med 2003, 349:1207-1215.

165. Finkelstein JS, Hayes A, Hunzelman JL, Wyland JJ, Lee H, Neer RM: The effects of parathyroid hormone, alendronate, or both in men with osteoporosis. N Engl J Med 2003, 349:1216-1226.

166. Stewart AF: PTHrP(1-36) as a skeletal anabolic agent for the treatment of osteoporosis. Bone 1996, 19:303-306.

167. Meunier PJ, Roux C, Seeman E, Ortolani S, Badurski JE Spector TD, Cannata J, Balogh A, Lemmel EM, Pors-Nielsen S, Rizzoli R, Genant HK, Reginster JY: The effects of strontium ranelate on the risk of vertebral fracture in women with postmenopausal osteoporosis. N Engl J Med 2004, 350:459-468.

168. Reginster JY, Seeman E, De Vernejoul MC, Adami S, Compston J, Phenekos C, Devogelaer JP, Curiel MD, Sawicki A, Goemaere S, Sorensen $\mathrm{OH}$, Felsenberg $\mathrm{D}$, Meunier PJ: Strontium ranelate reduces the risk of nonvertebral fractures in postmenopausal women with osteoporosis: Treatment of Peripheral Osteoporosis (TROPOS) study. J Clin Endocrinol Metab 2005, 90: 2816-2822.

169. Reginster JY, Felsenberg D, Boonen S, Diez-Perez A, Rizzoli R, Brandi ML, Spector TD, Brixen K, Goemaere S, Cormier C, Balogh A, Delmas PD, Meunier PJ: Effects of long-term strontium ranelate treatment on the risk of nonvertebral and vertebral fractures in postmenopausal osteoporosis: results of a five-year, randomized, placebo-controlled trial. Arthritis Rheum 2008, 58:1687-1695.

170. Seeman E, Vellas B, Benhamou C, Aquino JP, Semler J, Kaufman JM, Hoszowski K, Varela AR, Fiore C, Brixen K, Reginster JY, Boonen S: Strontium ranelate reduces the risk of vertebral and nonvertebral fractures in women eighty years of age and older. J Bone Miner Res 2006, 21:1113-1120.

171. Marquis $P$, Roux $C$, de la Loge $C$, Diaz-Curiel $M$, Cormier $C$, Isaia G, Badurski J, Wark J, Meunier PJ: Strontium ranelate prevents quality of life impairment in post-menopausal women with established vertebral osteoporosis. Osteoporos Int 2008, 19: 503-510.

172. Bekker PJ, Holloway DL, Rasmussen AS, Murphy R, Martin SW, Leese PT, Holmes GB, Dunstan CR, DePaoli AM: A single-dose placebo-controlled study of AMG 162, a fully human monoclonal antibody to RANKL, in postmenopausal women. $J$ Bone Miner Res 2004, 19:1059-1066.

173. Lewiecki EM, Miller PD, McClung MR, Cohen SB, Bolognese MA, Liu Y, Wang A, Siddhanti S, Fitzpatrick LA; AMG 162 Bone Loss Study Group: Two-year treatment with denosumab (AMG 162) in a randomized phase 2 study of postmenopausal women with low BMD. J Bone Miner Res 2007, 22:1832-1841.
174. McClung MR, Lewiecki EM, Cohen SB, Bolognese MA, Woodson GC, Moffett AH, Peacock M, Miller PD, Lederman SN, Chesnut $\mathrm{CH}$, Lain D, Kivitz AJ, Holloway DL, Zhang C, Peterson MC, Bekker PJ; AMG 162 Bone Loss Study Group: Denosumab in postmenopausal women with low bone mineral density. $N$ Engl J Med 2006, 354:821-831.

175. Miller PD, Bolognese MA, Lewiecki EM, McClung MR, Ding B, Austin M, Liu Y, San Martin J, Amg Bone Loss Study Group: Effect of denosumab on bone density and turnover in postmenopausal women with low bone mass after long-term continued, discontinued, and restarting of therapy: a randomized blinded phase 2 clinical trial. Bone 2008, 43:222-229.

176. Brown JP, Prince RL, Deal C, Recker RR, Kiel DP, de Gregorio LH, Hadji P, Hofbauer LC, Alvaro-Gracia JM, Wang H, Austin M, Wagman RB, Newmark R, Libanati C, San Martin J, Bone HG: Comparison of the effect of denosumab and alendronate on BMD and biochemical markers of bone turnover in postmenopausal women with low bone mass: a randomized, blinded, phase 3 trial. J Bone Miner Res 2009, 24:153-161.

177. Cummings S, San Martin J, McClung M, Siris E, Eastell R, Reid IR, Delmas P, Zoog HB, Austin M, Wang A, Kutilek S, Adami S, Zanchetta J, Libanati C, Siddhanti S, Christiansen C; FREEDOM Trial: Denosumab for prevention of fractures in postmenopausal women with osteoporosis. N Engl J Med 2009 361:756-765.

178. Geusens P: Emerging treatments for postmenopausal osteoporosis - focus on denosumab. Clin Interv Aging 2009, 4:241250.

179. Stoch SA, Wagner JA: Cathepsin K inhibitors: a novel target for osteoporosis therapy. Clin Pharmacol Ther 2008, 83:172176.

180. Li X, Ominsky MS, Warmington KS, Morony S, Gong J, Cao J, Gao Y, Shalhoub V, Tipton B, Haldankar R, Chen Q, Winters A, Boone T, Geng Z, Niu OT, Ke HZ, Kostenuik PJ, Simonet WS, Lacey DL, Paszty C: Sclerostin antibody treatment increases bone formation, bone mass, and bone strength in a rat model of postmenopausal osteoporosis. J Bone Miner Res 2009, 24: 578-588. 